\author{
Szymon TITKOW \\ https://orcid.org/0000-0002-3375-0882 \\ Uniwersytet Warszawski
}

\title{
Pieczęć królewicza Kazimierza Kazimierzowica Jagiellończyka z okresu starań o koronę węgierską i jej program polityczny
}

Zarys treści: Przedmiotem artykułu jest analiza pieczęci królewicza Kazimierza Kazimierzowica Jagiellończyka z okresu jego starań o koronę węgierską w latach 1471-1472. Po zaprezentowaniu źródła autor dokonuje interpretacji jego programu ideowo-politycznego w kontekście rywalizacji habsbursko-korwińsko-jagiellońskiej w trzeciej ćwierci XV w.

\begin{abstract}
The article deals with the seal of Prince Casimir Jagiellon (the second son of King Casimir IV) from the period of his claims to the Hungarian Crown in 1471-1472. After presenting the source material, the author interprets his ideological and political programme in the context of the rivalry between the Jagiellons, Habsburgs and Corvinus in the third quarter of the fifteenth century.
\end{abstract}

Słowa kluczowe: sfragistyka, heraldyka, Jagiellonowie, Habsburgowie, św. Kazimierz Jagiellończyk, Władysław Warneńczyk, polityka dynastyczna

Keywords: sphragistics, heraldry, Jagiellons, Habsburgs, St. Casimir Jagiellon, Władysław III of Varna, dynastic policy

Pieczęć królewicza Kazimierza ${ }^{1} \mathrm{z}$ okresu starań o koronę węgierską została wprowadzona do literatury przedmiotu przez Irenę Sułkowską-Kurasiową w 1967 r. ${ }^{2}$ Uwagi tej badaczki skorygował i częściowo uzupełnił Zenon Piech ${ }^{3}$. Chociaż problematykę tej pieczęci poruszano w historiografii już kilkakrotnie, nie doczekała się jednak dotąd pełniejszego opracowania4. Ostatnio, w publikacji poświęconej innej,

${ }^{1}$ Królewicz Kazimierz został kanonizowany w 1602 r. Tylko w tym miejscu zaznaczam przyznany mu status świętego, gdyż przedmiot artykułu nie ma związku z jego kultem. Zagadnienie to doczekało się ostatnio opracowania: S. Maslauskaitè-Mažylienė, Dzieje wizerunku św. Kazimierza od XVI do XVIII wieku. Między ikonografia a tekstem, thum. K. Korzeniewska, Wilno 2013.

2 I. Sułkowska-Kurasiowa, Polska kancelaria królewska w latach 1447-1506, Warszawa 1967, s. 72-74.

${ }^{3}$ Z. Piech, Średniowieczne herby w katedrze wawelskiej. Treści i funkcje, w: Katedra krakowska w średniowieczu. Materiaty sesji Oddziału Krakowskiego Stowarzyszenia Historyków Sztuki. Kraków kwiecień 1994, red. J. Daranowska-Łukaszewska, K. Kuczman, Kraków 1996, s. 140; tenże, Monety, pieczęcie i herby w systemie symboli władzy Jagiellonów, Warszawa 2003, s. 85.

${ }^{4}$ Problematykę pieczęci będącej przedmiotem artykułu poruszano w: I. Sułkowska-Kurasiowa, Polska kancelaria królewska, s. 74; Z. Piech, Średniowieczne herby, 140; tenże, Monety, pieczęcie i herby, s. 85-86, 210; tenże, Pieczęcie herbowe w systemach sfragistycznych dawnej Rzeczypospolitej, w: Dawne pieczęcie. Typologia, metody badań, interpretacje, red. Z. Piech, Warszawa 2015, s. 207-253; tenże, Austriacki herb Habsburgów w heraldyce Jagiellonów, w: Nihil superfluum esse. Prace z dziejów średniowiecza ofiarowane Profesor Jadwidze Krzyżaniakowej, red. J. Strzelczyk, J. Dobosz, Poznań 2000, s. 565-594; A. Jaworska, Orzeł Biały. Herb państwa polskiego, Warszawa 2003, zwł. s. 92-93; F. Kiryk, Królewicza Kazimierza Jagiellończyka działalność publiczna, St. Hist., 48, 2005, nr 1, s. 3-14; M. Hlebionek, Pieczęcie polskich 
nieznanej dotąd pieczęci królewicza z 1482 r., Sobiesław Szybkowski zebrał dotychczasowe ustalenia dotyczące pieczęci „węgierskiej”5. Niniejszy artykuł stanowi próbę spojrzenia na pieczęć królewicza Kazimierza w kontekście rywalizacji habsbursko-korwińsko-jagiellońskiej. Celem wywodu będzie wykazanie, że forma i treści pieczęci są nieprzypadkowe i stanowią przekaz, który można odczytywać jako manifestację praw królewicza Kazimierza do tronu węgierskiego. Rozważania te nawiązywać będą do wprowadzonej przez Z. Piecha koncepcji pozaprawnej funkcji pieczęci, która polega na przekazywaniu treści propagandowych ${ }^{6}$.

\section{Opis pieczęci}

Przedmiotem poniższych badań sfragistyczno-heraldycznych są zachowane trzy odciski pieczęci, z których wszystkie znajdują się w AGAD, w Zbiorze dokumentów pergaminowych ${ }^{7}$ (sygn. $5117^{8}$, $5119^{9}, 5120^{10}$ ). Czwarty znany dokument zachowany w oryginale znajduje się w Archiwum Miejskim w Koszycach (Schwarzenbach, sygn. 11880). Niestety zachował się na nim tylko ślad po pieczęci z czerwonego wosku $(65 \mathrm{~mm})$. Ten dokument doczekał się dwóch edycji ${ }^{11}$. Dokument w AGAD o sygnaturze 5120, z którego pochodzą zawarte w artykule fotografie pieczęci, znalazłem z luźną kustodią.

Pieczęć z $1471 \mathrm{r}$. jest okrągłą pieczęcią herbową (o średnicy $62 \mathrm{~mm}$ ), odciśniętą przez papier na podkładzie z czerwonego wosku, tuż pod tekstem, około połowy szerokości arkusza ${ }^{12}$. W polu pieczęci znajduje się herb złożony na czwórdzielnej tarczy. Według Z. Piecha zestaw herbów stanowią: I - Orzeł, II - herb starowęgierski, III - herb nowowęgierski, IV - Pogoń. Stwierdził on, że napis otokowy wykonany minuskułą gotycką jest nieczytelny, niemniej zaproponował fragmentaryczny odczyt: S(igillum) Kazi $[\ldots]^{13}$. Sądzę, że możliwy jest odczyt pełniejszy (liczba kropek w nawiasach stanowi domniemaną liczbę nieczytelnych znaków).

królewiczów, „Сфрагістичний щорічник”, 4, 2013, s. 158-184, s. 162; tenże, Systematyka polskich pieczęci królewskich wybrane zagadnienia, w: Dawne pieczęcie, s. 47-69; S. Szybkowski, Nieznana pieczęć królewicza Kazimierza z 1482 roku, Rocz. Hist., 81, 2015, s. 189-197; informację o istnieniu pieczęci wraz z sygnaturami dokumentów w AGAD, przy których występuje, podał K. Górski w biogramie królewicza w PSB; tenże, Kazimierz Jagiellończyk (1458-1484), w: PSB, t. 12, Wrocław 1966-1967, s. 286-288.

${ }^{5}$ S. Szybkowski, Nieznana pieczęć królewicza, s. 189-190. Badacz nie wspomina o nietrafnym odczycie kompozycji herbowej na pieczęci (za którą idzie jej błędna interpretacja) przez A. Jaworską; taż, Orzeł Biały, s. 92-93.

${ }^{6}$ Z. Piech, Ikonografia pieczęci Piastów, Kraków 1993, s. 11; tenże, Perspektywy polskich badań sfragistycznych, w: Pieczęcie dawnej Rzeczypospolitej. Stan i perspektywy badań, red. Z. Piech, J. Pakulski, J. Wroniszewski, Warszawa 2006, s. $31-58$, tu s. 33.

${ }^{7}$ Dokumenty, choć papierowe, są przechowywane w Zbiorze dokumentów pergaminowych AGAD. Już I. Sułkowska-Kurasiowa określiła tworzywo dokumentu (taż, Polska kancelaria królewska, s. 74), następnie stwierdził to też Z. Piech (tenże, Monety, pieczęcie i herby, s. 85), a w roboczym inwentarzu tego zbioru w odpowiedniej rubryce określono wszystkie trzy dokumenty jako pergaminowe.

${ }^{8}$ Dokument wystawiony w Hasrusch (25 XI 1471), królewicz Kazimierz poręcza w nim zapłatę żołdu dla oddziałów zaciężnych Wańka z Kłobuk, władyki Setryba i J. Czenieczskiego.

9 Dokument wystawiony w Nitrze (11 XII 1471), królewicz Kazimierz przyjmuje na służbę rotmistrza Macieja z Pławca.

${ }^{10}$ Dokument wystawiony w Nitrze (16 XII 1471), królewicz Kazimierz przyjmuje na służbę Wacława Wepursony z Laszkowa.

${ }^{11}$ Sprawozdanie z poszukiwań na Węgrzech dokonanych z ramienia Akademii Umiejętności, oprac. W. Baran, J. Dąbrowski, J. Łoś, J. Ptaśnik, S. Zachorowski, Kraków 1919, s. 55-56, nr 131; Dokumenty polskie z archiwów dawnego Królestwa Węgier, t. 2: Dokumenty z lat 1451-1480, wyd. S.A. Sroka, Kraków 2000, nr 245. Wcześniej dokument ten widział F. Papée i stwierdził, że „pieczęć [...] jest niestety startą nie do rozpoznania”, Dąbrowski zaś, opracowujący dokument w Sprawozdaniu z poszukiwań, podał informację, że dokument jest „ze śladami pieczęci in dorso”. Możliwe, że został tu uchwycony proces degeneracji zabytku; F. Papée, Wycieczka archiwalna do Węier, w: Studia i szkice z czasów Kazimierza Jagiellończyka, Warszawa 1907, s. 225-259 (o dok. zob. s. 255-256); Sprawozdanie z poszukiwań, s. 56.

${ }_{12}$ Uwagi o metodzie odciskania pieczęci przez papier por. M. Hlebionek, Uwagi krytyczne na marginesie pracy Władysława Fabijańskiego, „Pieczęcie papierowe z podkładem w zbiorze sfragistycznym Zakładu Narodowego im. Ossolińskich we Wrocławiu”, Zakład Narodowy im. Ossolińskich, Wrocław 2009, ss. 154, il. 147, St. Źródł., 49, 2001, s. 155-177, zwł. s. $166-167$.

${ }^{13}$ Z. Piech, Monety, pieczęcie i herby, s. 85-86. 


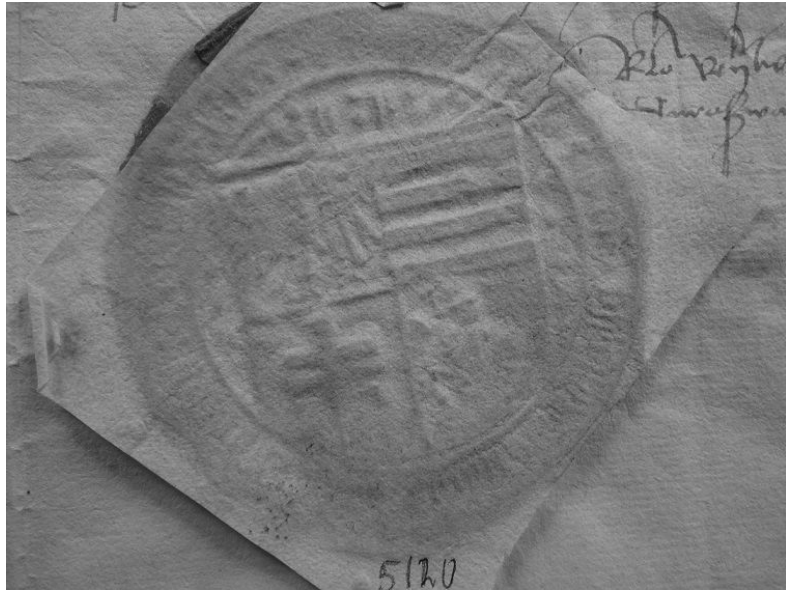

Il. 1 . Kustodia pieczęci królewicza Kazimierza; AGAD, Zbiór dokumentów pergaminowych, sygn. 5120

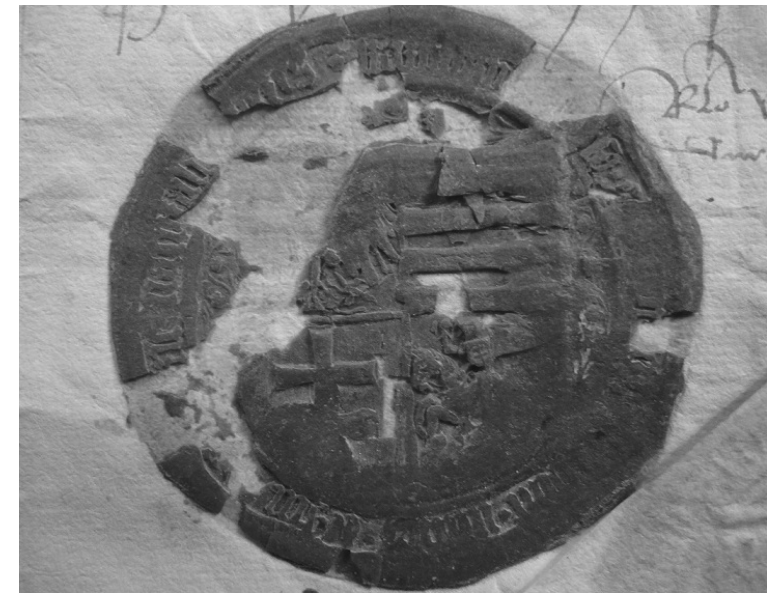

Il. 2. Odcisk pieczęci królewicza Kazimierza w wosku; AGAD, Zbiór dokumentów pergaminowych, sygn. 5120

\section{KAZIMIRU $[S] \cdot[D E] \mathrm{I}$ G(racia $) \cdot \mathrm{S}[\ldots] \cdot[\ldots . ..] \cdot \mathrm{NATUS} \cdot \mathrm{REGNI} \cdot[H U N G A] \mathrm{RIE} \cdot$ NATURALI $[S] \cdot[H E]$ RES}

Mimo że odczyt nadal pozostaje niepełny, rekonstrukcję napisu umożliwia ścisły związek jego formuły z tytulaturą stosowaną przez królewicza w dokumentach, która brzmi: „Kazimirus dei gracia serenissimi principis domini Kazimiri eadem gracia regis Polonie etc. natus et regni Hungarie naturalis heres etc.” Tytulatura została wprowadzona do literatury przedmiotu już przez I. Sułkowską-Kurasiową wraz z informacją o jej występowaniu we wszystkich znanych badaczce formułach relacyjnych pierwszego sekretarza, kanonika krakowskiego Stanisława Kurozwęckiego ${ }^{14}$. Identyczna formuła występuje w dokumencie $\mathrm{z}$ archiwum w Koszycach, którego wspomniana badaczka nie znała ${ }^{15}$.

Obecnie znamy siedem dokumentów królewicza wystawionych w związku z wyprawą węgierską ${ }^{16}$. Przytoczona tytulatura jest w nich używana konsekwentnie. Także wpis w XII księdze Metryki Koronnej niemieckojęzycznego dokumentu został opatrzony tytulaturą będącą dokładnym przekładem formuły łacińskiej na język niemiecki ${ }^{17}$. Z odmianą tytulatury mamy do czynienia w liście Kazimierza do cesarza Fryderyka III, o czym będzie mowa dalej.

Cechą tytulatury królewicza jest powoływanie się na ojcostwo króla Kazimierza Jagiellończyka ${ }^{18}$. W liście wypowiadającym wojnę Maciejowi Korwinowi ${ }^{19}$ tytulatura króla Kazimierza została uwzględniona

14 I. Sułkowska-Kurasiowa, Polska kancelaria królewska, s. 74.

${ }_{15}$ Dokumenty polskie z archiwów dawnego Królestwa Wegier, t. 2, nr 245.

16 Znamy jeszcze dokument wystawiony w Krakowie 16 XI 1471 (AGAD, Zbiór dokumentów pergaminowych, sygn. 5577), formalnie przez króla Kazimierza i królewicza Kazimierza, który jest tu tytułowany „illustrissimo domino Kazimiro Nato nostro carissimo naturali herede hungarie”. Pewną różnicę w tytulaturze królewicza można wytłumaczyć faktem wystawienia dokumentu przez polską kancelarię królewską, gdy sam królewicz był już na Węgrzech (wyprawa na Węgry wyruszyła 2 października; M. Plewczyński, Wojny Jagiellonów z wschodnimi i potudniowymi sąsiadami Królestwa Polskiego w XV wieku, Siedlce 2002, s. 64), a formuła koroboracyjna nie pozostawia wątpliwości, że dokument uwierzytelniono jedną pieczęcią - z całą pewnością królewską.

${ }_{17}$ MK, XII, f. 48; o rzeczonym wpisie wzmiankuje F. Kiryk, Królewicza Kazimierza Jagiellończyka działalność publiczna, s. 12.

18 Osobną problematyką jest odwoływanie się w tytulaturze czy w inskrypcjach napieczętnych na rodzinne koligacje - w kontekście pieczęci królewicza Kazimierza warto wskazać przypadki, gdy takie odwołania miały zazwyczaj na celu wskazanie na posiadane prawa dziedziczne. Jako przykład można podać znaną tytulaturę królowej Elżbiety (Národní Archiv Praha, Archiv České koruny (1158-1935), sygn. 1588, 1589; A. Różycka-Bryzek, Bizantyjsko-ruskie malowidta naścienne w kaplicy świętokrzyskiej na Wawelu (1470), „Studia do Dziejów Wawelu”, 3, 1968, s. 180), legendę pieczęci „głogowskiej” Zygmunta Jagiellończyka (M. Chmielewska, Pieczęć kancelaryjna Zygmunta Jagiellończyka jako księcia ślaskiego, Sobótka, 44, 1989, nr 4, s. 629-632; Z. Piech, Monety, pieczęcie i herby, s. 88-89) czy też fakt wprowadzenia na pieczęci wielkiej litewskiej Aleksandra opisu herbów rodowych (tamże, s. 103-106).

${ }^{19}$ MK, XII, f. 8, wyd. w: Codex diplomaticus Regni Poloniae et Magni Ducatus Lituaniae, t. 1, wyd. M. Dogiel, Wilno 1764, nr XIX. Jan Dąbrowski odnotowuje też współczesną kopię papierową (bez sygnatury) znajdującą się w Muzeum 
w zakresie szerszym niż w pozostałych, co może wynikać z faktu wystawienia dokumentu w Krakowie. Na podstawie przywołanych wyżej analogii można uznać, że w uszkodzonym napisie otokowym, przed zachowanym słowem natus (w znaczeniu 'syn'), znajdował się patronimik. Wziąwszy pod uwagę powyższe ustalenia, a także uwzględniając liczbę niezachowanych znaków w napisie i fakt, że litera $i$ w zachowanych partiach zajmuje stosunkowo niewielką przestrzeń, można zrekonstruować jego brzmienie następująco: KAZIMIRU $[S] \cdot[D E] \mathrm{I} \mathrm{G}($ racia $) \cdot \mathrm{S}[($ e)R(enissi $) M I] \cdot[$ KAZIMIRI $] \cdot \mathrm{NATUS} \cdot \mathrm{REGNI} \cdot$

$$
[H U N G A] \mathrm{RIE} \cdot \mathrm{NATURALI}[S] \cdot[H E] \mathrm{RES}
$$

Dodatkowymi elementami przekazu słownego w kompozycji napieczętnej, na które nie zwrócono dotąd uwagi, są umieszczone nad tarczą herbową dwa sygle i ornament roślinny. Niestety stan zachowania sygli na odcisku tłoka $\mathrm{w}$ wosku nie pozwala na ich odczytanie (pierwszy nie zachował się wcale, a drugi jedynie fragmentarycznie). Natomiast $\mathrm{z}$ istniejącego przedstawienia na kustodii można wnioskować, że wspomniane sygle to najprawdopodobniej: $\mathrm{k}: \mathrm{k}$, co pozwala stwierdzić, że zachowany fragment drugiego sygla przedstawia laskę minuskulnej litery $k$. Biorąc pod uwagę zarówno konieczność identyfikacyjnej funkcji inicjałów, jak i nieużywanie żadnego tytułu „,władczego” w tytulaturze, drugi z inicjałów - analogicznie do tytulatury - wskazywałby na ojca królewicza. W rozwinięciu imienia króla należy zastosować formę dopełniacza, taką jak w powiązanej z pieczęcią tytulaturze: $k$ (azimirus) : $k$ (azimiri). Drugim z elementów dotychczas nieodnotowanym w literaturze jest szczątkowo zachowany ornament roślinny wypełniający pierwotnie przestrzeń między tarczą herbową a napisem $\mathrm{w}$ otoku ${ }^{20}$.

Pieczęć królewicza stylistycznie bliska jest tzw. drugiej pieczęci podkanclerskiej króla Kazimierza Jagiellończyka (przedstawiającej Orła z Pogonią w układzie szachownicowym) ${ }^{21}$. Obie cechują się wysokim poziomem artystycznym projektu i wykonania, o czym świadczą zachowane ornamenty roślinne czy też podwójne krzyże widoczne na tarczkach Pogoni. Warto podkreślić podobieństwo między tymi pieczęciami, które wyraża się także w umieszczeniu nad tarczą herbową omówionych już inicjałów, co zostało wprowadzone po raz pierwszy do sfragistyki Jagiellonów właśnie na rzeczonej pieczęci króla Kazimie$\mathrm{rza}^{22}$. Różnicę między pieczęcią ojca i syna stanowi średnica - pieczęć królewiczowska ma $62 \mathrm{~mm}$, podczas gdy pieczęć podkanclerska Kazimierza mierzy $38 \mathrm{~mm}$, a kanclerska (większa koronna) - 48 mm²3.

Spośród wspomnianych dokumentów wystawionych przez królewicza w związku z wyprawą węgierską cztery zachowały się w oryginale, kolejne trzy zaś znamy z odpisów w XII księdze MK. Ich zakres chronologiczny obejmuje nieco ponad cztery miesiące, począwszy od daty listu wypowiadającego wojnę Maciejowi Korwinowi z 20 IX 1471, a kończąc na 30 I 1472, z którego pochodzi wspomniany list adresowany do Fryderyka III ${ }^{24}$. List i jego edycja autorstwa Antoniego Prochaski wymaga bliższego omówienia.

Siedmiogrodzkim w Koloszwarze (obecnie Kluż-Napoka w Rumunii). Powstanie oryginału datuje na 6 IX 1471, choć datacja wskazuje na 20 września („feria sexta in vigilia Mathei apostoli”); Sprawozdanie z poszukiwań, s. 54, nr 129.

${ }^{20}$ Uwzględnienie motywów roślinnych w badaniach sfragistycznych postuluje Z. Piech, Pieczęcie herbowe, s. 217-218. Niestety stan zachowania odcisku uniemożliwia bezdyskusyjną identyfikację rośliny. Na tyle, na ile pozwala stan zabytku, można $\mathrm{z}$ całą pewnością stwierdzić, że przedstawiona w ornamencie roślina jest kwiatem. Wnioskując z charakterystycznego kształtu liści i „kulek”, będących zapewne pąkami kwiatów, przypuszczam, że kwiatem tym jest piwonia. Szczególne podobieństwo w przedstawieniu ornamentu można dostrzec, porównując ze Studium peonii Martina Schongauera z ok. 1472 r.; S. Kobielus, Florarium christianum. Symbolika roślin - chrześcijańska starożytność i średniowiecze, Kraków 2006, s. 66, il. 220.

${ }_{21}$ M. Gumowski, Pieczęcie królów polskich, Kraków 1910, tabl. XI, nr 28; Sigilla regum et reginarum Poloniae. Pieczęcie królów i królowych Polski ze zbiorów Archiwum Głównego Akt Dawnych, Warszawa 2015, s. 24. Należy odnotować, że Kazimierz używał dwóch bardzo podobnych do siebie pieczęci, o czym pisze K. Wyczańska, O zaginionych pieczęciach Kazimierza Jagiellończyka, Przegl. Hist., 49, 1958, s. 530-537.

22 A. Jaworska, Orzet Biały, s. 236.

${ }^{23}$ Na kwestię wielkości pieczęci królewicza Kazimierza zwrócił uwagę już Z. Piech, wskazując, że była ona większa od największej pieczęci Kazimierza Jagiellończyka (wspomnianej większej koronnej), czyli od ówcześnie największej funkcjonującej pieczęci w kancelarii królewskiej. W obliczu ustaleń P. Węcowskiego, w wyniku których poświadczone jest funkcjonowanie pieczęci majestatowej przynajmniej od 1470 r., stwierdzenie Z. Piecha się zdezaktualizowało; Z. Piech, Monety, pieczęcie i herby, s. 85; P. Węcowski, Pieczęć majestatowa Kazimierza Jagiellończyka. Datacja oraz próba wyjaśnienia, dlaczego król przestat jej używać, St. Źródł., 49, 2011, s. 97-116.

${ }^{24}$ MK, XII, f. 61, wyd. A. Prochaska, Wyprawa św. Kazimierza na Węgry (1471-1474), „Ateneum Wileńskie”, 1, 1923, s. $20-28$, tu s. $26-27$. 
Przyjmując za podstawę edycji wpis w Metryce Koronnej, A. Prochaska najwyraźniej pominął dwa istotne elementy. Po pierwsze, opuścił nagłówek poprzedzający wpis listu, który brzmi: „d(omi)nus Kazimirus secundogenitus Reg(is) in S(an)cto Reg(no) Hung[ari]e ad Imp[er]atore[m] scribit". Należy podkreślić, że został on wprowadzony najprawdopodobniej już po dokonaniu wpisu. Jest on o tyle znaczący, że wskazuje na znajomość tytulatury królewicza używanej od zakończenia wojny z Maciejem ${ }^{25}$. Po drugie, badacz opuścił również umieszczoną pod tekstem, po lewej stronie, formułę „Е(iusdem) $\mathrm{v}($ estrae) s(erenitatis)" i następujący po niej, poniżej po prawej, podpis: „h(u)m(i)lis filius Kazimirus se(renissi)mi | p(ri)n(ci)pis Do(mi)n(i) Kazimiri R(egis) Polo(ni)e | natus Reg(n)i Hung(ari)e na(tura)lis d(omi)n(u)s". Jest to jedyna znana formuła podpisowa królewicza z okresu wyprawy węgierskiej, którą dodatkowo cechuje zbieżność zarówno z tytulaturą królewicza, jak i napisem otokowym omawianej pieczęci. Wydaje się to nieprzypadkowe w związku z tym, że wspomniana intytulacja listu w MK jest zapewne przynajmniej częściowo inwencją pisarza-kopisty, a tekst listu nie zawiera ani formuły koroboracyjnej, ani relacyjnej.

Kwestią otwartą jest tu interpretacja słowa scribit, które może stanowić przesłankę do stwierdzenia, że jeśli nie cały list był konceptem czy nawet autografem królewicza, to przynajmniej zamieszczona pod listem formuła podpisowa mogła być jego autografem ${ }^{26}$. Podpis monarszy w zwyczajach polskiej kancelarii królewskiej w tym czasie nie występował, a pojawił się dopiero za panowania Jana Olbrachta ${ }^{27}$. Dla rozważań nad kwestią podpisu królewicza warto uwzględnić znane literaturze podpisy Władysława Warneńczyka, którymi opatrzone były dokumenty wystawione po objęciu tronu węgierskiego, co wynika ze zwyczajów kancelarii węgierskiej ${ }^{28}$. Skłaniałoby to do uznania ewentualnego podpisu królewicza za jeden z elementów świadomie nawiązujących do zwyczajów tej kancelarii.

\section{Kontekst polityczny pieczęci}

Pieczęć królewicza Kazimierza Jagiellończyka z 1471 r. powstała w związku z jego staraniami o objęcie tronu węgierskiego, stanowiącymi element rywalizacji Jagiellonów z królem Węgier Maciejem Korwinem o koronę św. Wacława po śmierci Jerzego z Podiebradów ${ }^{29}$. Wiąże się to z prowadzoną przez Kazimierza Jagiellończyka polityką dynastyczną, mającą na celu przejęcie królestw Czech i Węgier, i zabezpieczenia tym samym południowych i południowo-wschodnich granic Korony. Plany osadzenia pierworodnego Władysława na tronie czeskim i drugiego z synów, Kazimierza, na tronie węgierskim były umotywowane także prawami do obu koron, jakie wniosła do rodu Jagiellonów królowa Elżbieta Rakuszanka $^{30}$. Pierwszą próbę ich realizacji podjęto po śmierci dzierżącego obie korony Władysława V

25 S. Szybkowski, Nieznana pieczęć królewicza, s. 190.

${ }^{26} \mathrm{~W}$ niezachowanej w oryginale księdze podkanclerzego Andrzeja Oporowskiego poświadczona jest późniejsza działalność kancelaryjna królewicza; zob. A. Prochaska, Czy autograf św. Kazimierza?, „Przegląd Powszechny”, 29, 1912, nr 66, s. 70-76. Badacz zamieścił fotografie obu stron pierwszej karty rejestru kwitacji prowadzonego przez królewicza; Księga Metryki Koronnej podkanclerzego Andrzeja Oporowskiego z lat 1479-1483, wyd. G. Rutkowska, Warszawa 2003, s. 24-25 (k. 151), s. 139.

27 I. Sułkowska-Kurasiowa, Polska kancelaria królewska, s. 70; E. Potkowski, Podpisy królów polskich, „Miscellanea Historico-Archivistica", 2, 1987, s. 25.

${ }^{28}$ E. Potkowski, Podpisy królów, s. 20-23. I. Sułkowska-Kurasiowa zwraca uwagę na interesujące zjawisko przenikania się zwyczajów kancelarii polskiej i węgierskiej podczas pobytu Władysława Warneńczyka na Węgrzech, czego efektem były m.in. dokumenty opatrzone królewskim podpisem, choć wystawione były dla polskiego odbiorcy; taż, Dokumenty królewskie i ich funkcja w państwie polskim za Andegawenów i pierwszych Jagiellonów 1370-1444, Warszawa 1977, s. 78, 81.

${ }^{29} \mathrm{O}$ wyprawie węgierskiej królewicza zob. K. Baczkowski, Między czeskim utrakwizmem a rzymska ortodoksja czyli walka Jagiellonów z Maciejem Korwinem o koronę czeska w latach 1471-1479, wyd. 2 popr., poszerz. i uzup., Oświęcim 2014, s. 59-66; T. Grabarczyk, Piechota zaciężna Królestwa Polskiego w XV wieku, Łódź 2000, s. 219-226; M. Plewczyński, Wojny Jagiellonów, s. 56-86; A. Prochaska, Wyprawa św. Kazimierza na Wegry, s. 20-28.

${ }^{30}$ Należy zaznaczyć, że w dokumencie z 6 III 1454 Elżbieta zrzekła się wszelkich praw do tronów Czech i Węgier na rzecz Władysława Pogrobowca i jego ewentualnych przyszłych potomków. Znamienne jest sformułowanie podkreślające, że królowa rezygnowała z praw tak po ojcu, jak o matce („Successionum sive devolutionum, quae Nobis Jure Paterno, sive 
Pogrobowca, ostatniego po mieczu męskiego przedstawiciela starszej, albertyńskiej linii Habsburgów. Kazimierz IV wysłał wtedy poselstwa do Czech i Węgier, upominając stany obu krajów o prawach swych synów ${ }^{31}$. Ponieważ wysiłek państwa polskiego był nastawiony na toczącą się właśnie wojnę trzynastoletnią z zakonem krzyżackim, poprzestano jedynie na działaniach dyplomatycznych. Wskazanie na dziedziczne prawa Kazimierzowiców nie przyniosło rezultatu, a tron objęli tzw. królowie narodowi: w Czechach Jerzy z Podiebradów, a na Węgrzech Maciej Korwin. Jak zobaczymy, doświadczenie to wpłynęło na zmianę polityki króla Kazimierza wobec obu krajów.

Po porażce obu misji poselskich podjęto próby stworzenia dogodnych warunków przejęcia władzy w obu krajach. Być może wzorowano się na posunięciach cesarza Fryderyka III Habsburga, który układami w Wiener-Neustadt i Sopronie (1463) zagwarantował swemu rodowi następstwo po śmierci Macieja Korwina na tronie Węgier. Znaczący był w tych traktatach fakt uznania przez cesarza praw stanów węgierskich do dokonania wyboru władcy. Poprzez połączenie kwestii praw dziedzicznych i dopuszczenia pewnych elementów elekcyjności tronu (stany węgierskie mogły wybrać któregoś z potomków Fryderyka III) Habsburgowie zabezpieczyli sobie przejęcie tronu węgierskiego ${ }^{32}$.

Podobny kierunek działania obrała strona polska, starając się o tron czeski dla królewicza Władysława. Zgodnie z uchwałą przyjętą przez sejm czeski, w obecności posłów polskich, na tron Czech po śmierci Jerzego z Podiebradów miał wstąpić pierworodny syn polskiej pary królewskiej ${ }^{33}$. Ostatecznie Władysław Jagiellończyk objął tron Czech w wyniku elekcji w Kutnej Horze w 1471 r. Wcześniej, w 1469 r. w Ołomuńcu katoliccy panowie czescy proklamowali królem Macieja Korwina. Dla stronnictwa węgierskiego króla elekcja kutnohorska miała być tylko potwierdzeniem wcześniejszego wyboru $^{34}$. Gdy zgromadzenie w Kutnej Horze zaczęło się skłaniać ku kandydaturze Władysława, zwolennicy Macieja odjechali i rozpoczęły się przygotowania do wojny. Zmagania z Maciejem Korwinem trwały do 1474 r. i zakończyły się zawarciem rozejmu wrocławskiego, faktycznie dzielącego koronę św. Wacława między obydwu elektów ${ }^{35}$.

W obliczu zakończonego niepowodzeniem planu pokojowego przejęcia tronu w Pradze i wybuchu wojny z Maciejem podjęto decyzję o wysłaniu ekspedycji na Węgry celem zrzucenia Korwina z tronu. Zgodnie z założeniami, wraz z wkroczeniem królewicza na Górne Węgry do wojsk Kazimierzowica dołączyć mieli licznie węgierscy możnowładcy, mający dosyć absolutyzującej polityki Macieja Korwina. Formę, w jakiej Kazimierz miał odebrać mu władzę przedstawia zachowany akt wypowiedzenia wojny i znany z kopii w XII księdze MK dokument identyfikowany przez A. Prochaskę jako „otwarte pisma

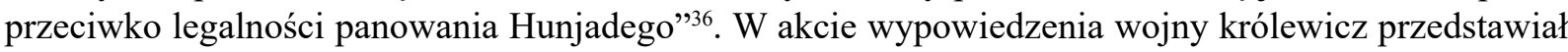
się jako wybawca ciemiężonej przez Korwina ludności Węgier, a także możnowładztwa i Kościoła. Zarzucał adwersarzowi brak jakichkolwiek praw do tronu, który zajął on przemocą. Powołując się na więzy krwi z Zygmuntem Luksemburskim i Władysławem V Pogrobowcem, uważał się za uprawnionego do objęcia korony. To stwierdzenie jest niezwykle istotne dla rozważań nad wymową jego pieczęci, ponieważ rozwiewa wszelkie wątpliwości dotyczące podstaw prawnych wystąpienia Kazimierza po koronę węgierską. Powołanie się na pokrewieństwo z Zygmuntem i Władysławem wskazuje, że podstawą roszczeń są dziedziczne prawa dynastyczne wniesione przez matkę Kazimierza - Elżbietę Rakuszankę (odpowiednio wnuczkę i siostrę tychże monarchów). Dopełnieniem aktu wypowiedzenia

Materno competiissent"). Wziąwszy pod uwagę fakt, że Władysław zmarł bezpotomnie, prawa Elżbiety do wspomnianych koron (przeniesione na jej synów) pozostały aktualne; Národní Archiv Praha, Archiv České koruny (1158-1935), sygn. 1588.

${ }_{31}$ M. Biskup, Die dynastische Politik der Jagiellonen um das Jahr 1475 und ihre Ergebnisse, „Österreichische Osthefte”, 18, 1976, s. 207; tenże, Die Rivalität zwischen Jagiellonen und Habsburgern um die böhmische und die ungarische Krone im 15. und Anfang des 16. Jahrhunderts, „Österreichische Osthefte”, 32, 1990, nr 2, s. 271.

${ }^{32}$ K. Baczkowski, Walka o Węry w latach 1490-1492. Z dziejów rywalizacji habsbursko-jagiellońskiej w basenie środkowego Dunaju, „Zeszyty Naukowe Uniwersytetu Jagiellońskiego. Prace Historyczne”, 116, 1995, s. 13; M. Biskup, Die Rivalität zwischen Jagiellonen und Habsburgern, s. 273.

33 R. Heck, Elekcja kutnohorska 1471 r., Sobótka, 27, 1972, nr 2, s. 203.

${ }^{34}$ K. Baczkowski, Między czeskim utrakwizmem, s. 17-18.

35 Tamże, s. 144-213.

${ }^{36}$ A. Prochaska, Wyprawa św. Kazimierza na Węgry, s. 13. 
wojny jest wspomniane pismo przeciw legalności władzy Macieja. Podstawowym argumentem do złożenia Korwina z tronu jest uznanie jego elekcji za nieważną, gdyż przeprowadzono ją siłą, a nie poprzez wolny wybór stanów. Znamienne jest tym samym uznanie legalności elekcji króla jako takiej, z zakwestionowaniem jedynie jej trybu, jako niezgodnego z normą.

Wyprawa królewicza Kazimierza zakończyła się klęską. Choć początkowo tylko 9 komitatów dochowało wierności Maciejowi ${ }^{37}$, to udało mu się odzyskać poparcie większości możnych poprzez poczynienie pewnych ustępstw na rzecz stanów. W zamian za poparcie i wyższe podatki w związku z wojną Korwin zagwarantował m.in. wolność osobistą i nietykalność majątkową szlachty ${ }^{38}$, a także zobowiązał się do corocznego zwoływania sejmu ${ }^{39}$. Utrata poparcia ze strony możnych węgierskich dla sprawy Kazimierza jest uważana za główną przyczynę porażki. Fiasko ekspedycji odbierano jako kompromitację polityki jagiellońskiej, co można wnosić choćby z wymownego milczenia o węgierskich aspiracjach dynastii $\mathrm{w}$ traktacie pokojowym kończącym wojnę z Maciejem Korwinem ${ }^{40}$.

\section{Program ideowy pieczęci}

Dla interpretacji programu heraldycznego pieczęci królewicza Kazimierza zasadniczą kwestią jest umieszczenie go w kontekście wyjątkowych okoliczności, czyli próby zdobycia tronu węgierskiego, co implikuje jego pretendencki charakter. Mianem pieczęci pretendenckiej określił ją Z. Piech, który jako źródło specyfiki pieczęci wskazywał właśnie kompozycję heraldyczną ${ }^{41}$. Badacz ów stwierdził, że tworząc kompozycję heraldyczną zamieszczoną na pieczęci królewicza Kazimierza, wykorzystano ten sam zestaw herbów, co na pierwszej pieczęci węgierskiej Władysława Warneńczyka ${ }^{42}$ (I - herb starowęgierski, II - Orzeł, III - Pogoń, IV - herb nowowęgierski ${ }^{43}$ ). Różnica między programami heraldycznymi polega, jego zdaniem, na kolejności ułożenia godeł w kompozycji wielopolowej - na pieczęci królewicza kolejność jest odwrócona (I - Orzeł, II - herb starowęgierski, III - herb nowowęgierski, IV - Pogoń), czego przyczynę widział badacz właśnie w owym pretendenckim charakterze pieczęci ${ }^{44}$.

Kategorię pretendenckości pieczęci odnosiłbym przede wszystkim do elementów znaczących konkretnego zabytku sfragistycznego, nie traktując jej jako określenia osobnego zbioru sfragistycznego. Odmienna natura roszczeń, jak i ich różne uwarunkowania polityczne powodują, że taki zbiór byłby bardzo zróżnicowany. Dobrze to obrazuje porównanie węgierskiej pieczęci królewicza Kazimierza z analogiczną pieczęcią króla Kazimierza jako króla-elekta czeskiego. Pieczęć owa powstała w związku z próbą objęcia tronu czeskiego po śmierci Zygmunta Luksemburskiego w $1437 \mathrm{r} .{ }^{45}$ Przedstawiała Pogoń, a częściowo zachowana legenda głosiła: „Kazimirus [Dei gratia rex] electus Bohemie”46. Niewątpliwie na ten relatywnie skromny program ideowo-polityczny wpłynął fakt, że jedynym filarem kandydatury Kazimierza był dokonany akt elekcji, podczas gdy pieczęć węgierska jego syna - jak postaram się wykazać - stanowi w swej istocie wykładnię praw do tronu kandydata.

${ }^{37} \mathrm{~K}$. Baczkowski, Idea jagiellońska a stosunki polsko-węgierskie w XV wieku, w: Polska i Węry w kulturze i cywilizacji europejskiej, red. J. Wyrozumski, Kraków 1997, s. 68.

38 T. Grabarczyk, Piechota zaciężna, s. 36.

39 S. Russocki, Monarchie stanowe środkowo-wschodniej Europy XV-XVI wieku, Kwart. Hist., 84, 1972, nr 1, s. 88.

${ }^{40}$ M. Biskup, Die dynastische Politik der Jagiellonen, s. 212.

${ }^{41}$ Z. Piech, Monety, pieczęcie i herby, s. 85.

${ }^{42}$ M. Gumowski, Pieczęcie królów polskich, tabl. X, nr 22.

${ }^{43}$ Szczegółowo temat herbu w czwartym polu na tej pieczęci Władysława Warneńczyka rozwijam w części poświęconej herbowi nowowęgierskiemu.

${ }^{44}$ Z. Piech zauważa, że herby węgierskie przysługiwały Kazimierzowi ze względu na prawa do korony węgierskiej, a nie fakt bycia królewiczem. Nie wyjaśnia on przy tym, czy ma tu na myśli status królewicza polskiego, czy węgierskiego, co powoduje, że ustęp ten jest nieprecyzyjny; tenże, Pieczęcie herbowe, s. 215.

${ }^{45} \mathrm{Na}$ temat walki Jagiellonów o tron czeski po śmierci Zygmunta Luksemburskiego zob. R. Heck, Tabor a kandydatura jagiellońska w Czechach (1438-1444), Wrocław 1964.

${ }^{46}$ M. Hlebionek, Nieznana pieczęć króla elekta Stanisława I, Rocz. Herald., 15(26), 2016, s. 71; KDWlkp., t. 5, Poznań 1908, nr 6370 (dd Biecz, 14 IX 1439). 
W kontekście pieczęci pretendenckich jest też oczywiste, że mogły one również zawierać takie treści tylko w pewnej mierze. Przykładem może być pieczęć większa koronna Aleksandra ${ }^{47}$, na której zastąpiono tzw. herb kaliski, odnoszący się do całej dzielnicy wielkopolskiej, herbem hospodarstwa mołdawskiego ${ }^{48}$. Znamienne, że w tym czasie hospodar Stefan Wielki uznawał zwierzchnictwo Władysława II, króla Czech i Węgier ${ }^{49}$. Kwestia pretendenckiego charakteru pieczęci i zakresu w ich programie roszczeniowych treści jest względna, a każdy przypadek należy traktować osobno ${ }^{50}$. W kontekście „węgierskiej” pieczęci królewicza Kazimierza nie ulega wątpliwości, że omawiany charakter wynika ze statusu i działań jej dysponenta. Stwierdzenie pretendenckiego statusu pieczęci powoduje, że wymaga ona szczegółowej analizy na tle towarzyszących jej wydarzeń historycznych.

Zaproponowana przez Z. Piecha koncepcja pretendenckiego charakteru omawianej pieczęci nie wyczerpuje, jak sądzę, tej problematyki. Wiąże się to z niekoherentną interpretacją charakteru herbów składających się na jej kompozycję heraldyczną. Orzeł i Pogoń w skrajnej parze mają zasadniczo określać właściciela pieczęci, a skoro królewicz nie pełnił żadnego urzędu w Koronie ani na Litwie, Z. Piech słusznie określił ich funkcję jako rodową. Natomiast herby królestwa Węgier są ujęte w charakterze państwowym i mają przedstawiać zakres roszczeń ${ }^{51}$.

Interpretacja pieczęci królewicza Kazimierza wymaga wyjaśnienia faktu odwrócenia kolejności herbów względem kompozycji heraldycznej znanej ze wspomnianej pieczęci węgierskiej Władysława. Układ herbów umieszczony na pieczęci Warneńczyka jest w pełni uzasadniony i nie budzi wątpliwości. Władca (tu: król) dwóch krajów ${ }^{52}$ łączy ich herby w jedną kompozycję, która ma oddać równorzędność obu całości w sposób, który spośród możliwych dostępnych konstrukcji herbowych najlepiej wyraża równorzędnośćs ${ }^{53}$. Godło węgierskie rozpoczyna czteropolową kompozycję z racji węgierskiego adresata

47 M. Gumowski, Pieczęcie królów polskich, tabl. XII, nr 38.

${ }^{48}$ Warto zauważyć, że istnieją przekazy źródłowe, które już w okresie rządów Kazimierza IV Jagiellończyka (1485) interpretowały umieszczoną na pieczęci monarszej głowę wołu jako herb Mołdawii, co oczywiście można potraktować jako błąd autora wypowiedzi, jednak w kontekście późniejszej ewolucji herbu wzmianka jest warta rozpatrzenia; Akta Stanów Prus Królewskich, t. 1, wyd. M. Biskup, K. Górski, Torun 1955, nr 200, s. 307.

49 S. Szybkowski, Uwagi o pieczęciach Aleksandra Jagiellończyka, St. Źródł., 51, 2013, s. 40. W traktacie polsko-mołdawskim wystawionym przez Jana Olbrachta w Krakowie 15 IV 1499 pominięto całkowicie kwestię zależności lennej Mołdawii od Polski; K. Niemczyk, Mołdawia Bogdana III Ślepego w polityce Aleksandra Jagiellończyka, w: Jagiellonowie i ich świat. Dynastia królewska w drugiej połowie XV i w XVI wieku, red. B. Czwojdrak, J. Sperka, P. Węcowski, Kraków 2015, s. 173-186, tu s. 174; Z. Spieralski, Awantury mołdawskie, Warszawa 1967, s. 64; o relacjach polsko-węgierskich w kontekście wyprawy mołdawskiej Jana Olbrachta zob. K. Baczkowski, Stosunki między elitami władzy Polski i Węgier na przełomie XV i XVI wieku, „Zeszyty Naukowe Uniwersytetu Jagiellońskiego. Prace Historyczne”, 130, 2003 , s. 76-78.

${ }^{50}$ Kwestię pretendenckich pieczęci jako oddzielnej kategorii poruszyli także M. Hlebionek i P. Pokora, na marginesie uwag do wydanego przez AGAD zbioru pieczęci, postulując wniesienie pieczęci nazwanej „roszczeniową” Jana Luksemburskiego (w dokumencie, przy którym przywieszono omawianą pieczęć, Jan tytułuje się wprost królem Polski; AGAD, Zbiór dokumentów pergaminowych, sygn. 0010). Abstrahując od samego wydawnictwa i problemów z nim związanych, powstaje pytanie, czy taka pieczęć powinna się znaleźć w danym katalogu ze względu na przedmiot pretensji (tu: Królestwo Polskie), czy genezy sfragistycznej (czeska tradycja sfragistyczna). W tym wypadku włączenie pieczęci Jana byłoby z pewnością uzasadnione, gdyby potraktować wspomniane wydawnictwo, zgodnie z rzeczywistością, jako katalog bardziej okazałych zabytków sfragistycznych przechowywanych w AGAD, nie zaś jako „ogólnopolski” katalog pieczęci królewskich, do którego wydawnictwo zdaje się pretendować; ciż, Refleksje o „Pieczęciach królów i królowych Polski”, St. Źródł., 50, 2012, s. 112-122.

${ }^{51}$ Z. Piech, Monety, pieczęcie i herby, s. 210; stanowisko tego badacza podziela S. Szybkowski, Nieznana pieczęć królewicza, s. 192.

${ }^{52}$ Mimo rządów Kazimierza Jagiellończyka na Litwie, Władysław Warneńczyk zachował tytuł Najwyższego Księcia Litwy, co zostało zaznaczone na pieczęci majestatowej króla. Stąd Koronę i Wielkie Księstwo traktuję w tym kontekście jako całość. R. Kiersnowski stwierdza, że Władysław Warneńczyk nie był wielkim księciem i w konsekwencji interpretuje Pogoń na pieczęci jedynie w sferze dynastycznej; tenże, Godła jagiellońskie, w: Historia, pieniadz, herb. Opera selecta, red. S.K. Kuczyński, S. Suchodolski, Warszawa 2008, s. 447-471; o pieczęci Warneńczyka zob. s. 468-469. Pogląd tego badacza powtarza A. Jaworska, Orzet Biaty, s. 90.

${ }^{53}$ Równorzędność dwóch całości leży też u genezy kompozycji heraldycznej odzwierciedlającej wzajemny stosunek Polski i Litwy; por. J. Wyrozumski, Herb polsko-litewski i jego sens ideowy, w: Tradycje i perspektywy nauk pomocniczych historii w Polsce, red. M. Rokosz, Kraków 1995, s. 107-110, o genezie herbu zob. s. 107-108; Z. Piech, Monety, pieczęcie i herby, 
pieczęci króla Węgier. Gdyby w ten sposób spojrzeć na pieczęć królewicza, można by dojść do wniosku, że zakres jego władzy był tożsamy ze stryjowskim, tyle że w odniesieniu do państwa polsko-litewskiego. Taki wniosek byłyby oczywiście błędny. Widać zatem, że interpretacja traktująca zestaw herbów na pieczęci kazimierzowskiej jako państwowe nie wyczerpuje treści ideowej stojącej za programem heraldycznym pieczęci. Ogranicza ona także jej przekaz, pozwalając jedynie zidentyfikować pretendenta i przedmiot pretensji, pomijając zaś kwestię uzasadnienia jego roszczeń. Przypuszczam, że połączenie tych dwóch zespołów herbów wymusza ich spójną wymowę. Postaram się wykazać, że całość kompozycji heraldycznej należy traktować jako rodową, co pozwoli też na szerszą interpretację pieczęci.

Zgodnie ze wspomnianą koncepcją zinterpretuję tę pieczęć królewiczowską jako szczególny rodzaj pieczęci osobistej, zarazem niewątpliwie pretendenckiej. W ten sposób całą istniejącą kompozycję herbową można odczytać jako herb genealogiczny, na co zresztą wskazuje odwołująca się do praw dziedzicznych legenda pieczęci. Przy takiej interpretacji kompozycja składa się z dwóch równorzędnych części: paternum (I - Orzeł, IV - Pogoń) i maternum (II - herb starowęgierski, III - herb nowowęgierski), gdzie zachowane zostaje tradycyjnie dostojniejsze miejsce dla części ojcowskiej. W ten sposób zrozumiałe staje się ułożenie wyżej w hierarchii Orła i Pogoni względem herbów węgierskich, a także uzyskujemy zgodność kompozycji herbowej z legendą w otoku. Pierwsza jej część określa królewicza jako syna Kazimierza, podstawę zaś do określania siebie mianem Regni Hungariae naturalis heres dają mu herby po matce - Elżbiecie Rakuszance. W kontekście prezentacji roszczeń do tronu węgierskiego należy zwrócić uwagę na fakt przedstawienia Kazimierza ,jedynie” jako mającego dziedziczne prawa, bez określenia go mianem króla węgierskiego ${ }^{54}$. Koreluje to z przytoczonym wyżej stwierdzeniem o zaakceptowaniu zasady elekcyjności tronu. Jak sądzę, należy ten fakt interpretować jako ukłon w stronę węgierskich możnych.

\section{Herby macierzyste (maternum)}

Zasadność określenia Orła i Pogoni jako elementów paternum nie ulega wątpliwości ${ }^{55}$. Przejdę zatem do omówienia i interpretacji herbów użytych jako maternum. Pierwszym z zaklasyfikowanych przeze mnie jako element maternum jest herb starowęgierski - drugi w układzie czteropolowej tarczy omawianej pieczęci. Jego przesłanie jest według mnie dość oczywiste i nie budzi wątpliwości. W kontekście kompozycji herbowej na pieczęci królewicza Kazimierza należy podkreślić przede wszystkim dynastyczną wymowę herbu. Włączenie herbu starowęgierskiego, funkcjonującego ówcześnie także jako najważniejszy element wywodu rodowego królowej Elżbiety ${ }^{56}$, służyło manifestacji praw synów polskiej pary królewskiej do luksemburskiego dziedzictwa, wskazując na prawa zyskane dzięki matce - dziedziczce Luksemburgów wywodzącej się z Habsburgów albertyńskich.

Kolejny element kompozycji herbowej pieczęci królewicza Kazimierza zaklasyfikowany przeze mnie jako element maternum wymaga szerszego wyjaśnienia. Herb nowowęgierski występował często w sfragistyce Zygmunta Luksemburskiego, zajmując centralną pozycję w programie heraldycznym, co widać szczególnie na rewersach dwustronnych węgierskich pieczęci majestatowych

s. 235-236; M.A. Janicki, Polityczny program ideowy tumby Władysława Jagielty a czas jego powstania, „Średniowiecze Polskie i Powszechne", 7(11), 2015, s. 95-159, tu s. 128-129.

${ }_{54}$ Por. przyp. 50.

55 Por. Z. Piech, Monety, pieczęcie i herby, s. 85.

${ }_{56}$ Problematyka heraldyki królowej Elżbiety stanowi osobny, nie dość jeszcze rozpoznany wątek, który zasługuje na osobne opracowanie. W tym miejscu zwrócę tylko uwagę na fakt, że w tym okresie (w trzeciej ćwierci XV w.) najważniejszym elementem wywodu genealogicznego królowej był herb starowęgierski, co jest widoczne na pieczęci królowej, gdzie zajmuje drugie miejsce, przed położonym na piątym miejscu w porządku heraldycznym pasem Habsburgów. Dodatkowo jeden ze zworników Kaplicy Świętokrzyskiej przedstawia tarczę herbową ze złożonymi szachownicowo Orłem i Wrębami, którą to kompozycję niewątpliwie należy wiązać z Elżbietą; por. Z. Piech, Średniowieczne herby, s. 139-140; tenże, Austriacki herb Habsburgów, s. 573-4; S. Szybkowski, Przyczynki do sfragistyki Jagiellonów na podstawie materiałów z archiwum państwowego w Gdańsku, „Rocznik Gdański”, 71-72, 2011-2012, s. 14-17. 
tego władcy ${ }^{57}$. Herb ten, mający rangę państwowego, wiąże się z tradycją św. Władysława, króla Węgier z dynastii Arpadów, którego kult był przez Zygmunta propagowany ${ }^{58}$. Warto zaznaczyć, że zarówno w sfragistyce Albrechta II i Władysława V, jak i na zabytkach związanych z Elżbietą Rakuszanką herb nowowęgierski zostaje zasadniczo wyparty z pieczęci przez pas Habsburgów ${ }^{59}$. Podstawa do użycia go w kompozycji - analogicznie do herbu starowęgierskiego - ma przede wszystkim walor dynastyczny, ponieważ jest oznaką praw do dziedzictwa po Zygmuncie Luksemburskim, co pozwala na oficjalne funkcjonowanie jako element maternum, herb ten ma też szczególne konotacje $\mathrm{z}$ domem jagiellońskim. By w pełni uchwycić stopień złożoności kompozycji heraldycznej królewicza Kazimierza, przejdę do omówienia relacji między herbem nowowęgierskim a podwójnym krzyżem Jagiellonów.

\section{Konotacje podwójnego krzyża Jagiellonów}

W literaturze przedmiotu przyjmuje się, że podwójny krzyż Jagiellonów funkcjonował początkowo jako herb osobisty króla Władysława Jagiełły ${ }^{60}$, który następnie został przejęty przez jego sukcesorów. Zaznaczam, że przedmiotem niniejszych rozważań jest podwójny krzyż występujący samodzielnie na oddzielnej tarczy herbowej, problematyka związana z jego występowaniem na tarczach Pogoni jest kwestią zasługującą na osobne opracowanie. Przechodząc do analizy źródeł sfragistycznych, można stwierdzić, że początkowo był on umieszczany na pieczęciach królewskich na osobnej tarczce ponad główną tarczą herbową. Takie położenie implikuje rodowy, a w przypadku Jagiełły osobisty charakter herbu. Znamienne, że samodzielna tarcza z podwójnym krzyżem Jagiellonów występowała tylko i wyłącznie na pieczęciach królewskich - na pieczęciach niekoronowanych potomków królów polskich oraz polskich królowych czy wielkich książąt litewskich z dynastii Jagiellonów herb ten nie występuje, co potwierdza jego ścisły związek z osobą króla polskiego. Wyjątkowy charakter podwójnego krzyża podkreśla też fakt, że herb występował na pieczęciach w uprzywilejowanej, rodowej pozycji, towarzysząc tylko kompozycji przedstawiającej pełniejsze odwzorowanie władztwa. Mam tu na uwadze pieczęcie większe herbowe pierwszych czterech królów z dynastii jagiellońskiej, które zawierają Orła, Pogoń, herb Wielkopolski, Kujaw i w przypadku pieczęci Jana Olbrachta także Rusi. Natomiast pieczęcie o programie zredukowanym do naprzemiennie położonych Orła i Pogoni pozbawione są wątku rodowego ${ }^{61}$.

Istotna zmiana w funkcjonowaniu podwójnego krzyża zachodzi wraz z objęciem tronu przez Władysława Warneńczyka. Wówczas herb pierwotnie osobisty zaczyna się przekształcać w rodowy, a w tym przypadku dynastyczny. Widać, że na pieczęci większej koronnej tego króla omawiany herb zajmuje analogiczną pozycję jak w sfragistyce protoplasty dynastii ${ }^{62}$. Za panowania Kazimierza Jagiellończyka

57 Taką pozycję zajmuje na trzech dwustronnych pieczęciach majestatycznych węgierskich (Sigismundus Rex et Imperator. Kunst und Kultur zur Zeit Sigismundus von Luxemburg 1387-1437. Ausstellungskatalog, red. I. Takács, Mainz 2006, il. 3.11, s. 183; il. 3.22, s. 190) czy piątej i szóstej sekretnej węgierskiej (tamże, il. 3.15, s. 185; il. 3.23, s. 190) lub dwustronnej pieczęci Zygmunta cesarskiej (tamże, il. 318, s. 186-187); jest to kontynuacja modelu pieczęci wyniesionej od Andegawenów, którzy przejęli go od Arpadów; por. I. Takács, Az Árpád-házi királyok pecsétjei, Corpus sigillorum Hungariae mediaevalis, t. 1, Budapest 2012.

${ }_{58}$ M.A. Janicki, Polityczny program ideowy, s. 156.

${ }^{59} \mathrm{O}$ pasie Habsburgów w kontekście pieczęci Kazimierza zob. dalej.

${ }^{60}$ R. Kiersnowski, Godła jagiellońskie, s. 463-468; Z. Piech, Monety, pieczęcie i herby, s. 243-268; M.A. Janicki, Polityczny program ideowy (na temat podwójnego krzyża zob. Ekskurs 3, s. 155-156). Problematyce związanej z podwójnym krzyżem jagiellońskim mam zamiar poświęcić osobną pracę.

${ }^{61}$ Zauważa to S.K. Kuczyński w kontekście pieczęci króla Kazimierza, stwierdzając, że taka kompozycja herbowa była drugorzędna i stosowano ją na pieczęciach mniejszych władcy; tenże, Polskie herby ziemskie: geneza, treści, funkcje, Warszawa 199, s. 35. Można więc przypuszczać, że tarczka z podwójnym krzyżem umieszczana była w celu dodatkowego wskazania na większą z pieczęci herbowych. Wyjątkiem jest tu tzw. pierwsza większa pieczęć herbowa Jagiełly, co można uzasadnić najwcześniejszym okresem rozwoju sfragistyki Jagiellonów, kiedy dopiero się ona kształtowała; M. Gumowski, Pieczęcie królów polskich, tabl. VIII, nr 15.

${ }^{62}$ Badająca kancelarię królewską Jagiełły I. Sułkowska-Kurasiowa doszła do wniosku, że nie ustaliła się praktyka stosowania konkretnego rodzaju pieczęci do określonych typów dokumentów; taż, Dokumenty królewskie, s. 50-65. 
herb utrzymuje swą funkcję herbu rodowego, co zostaje podkreślone przez graficzną zmianę podwójnego krzyża. Jak widać na pieczęci i na detalu z nagrobka króla przyjmuje on charakterystyczną formę. Wszystkie belki są prostopadle zakończone, a belki poprzeczne są równej długości i dodatkowo są rozmieszczone symetrycznie na pionowej belce, w równej odległości od jej końców ${ }^{63}$. Przyjmuję, że jest to zasadnicza ewolucja formy z krzyża patriarszego (a więc o dłuższej dolnej belce) i stanowi udzielną figurę heraldyczną ${ }^{64}$. Stąd herb z taką właśnie formą podwójnego krzyża zaklasyfikowałbym jako w pełni rozwiniętą formę królewskiego herbu rodowego członków dynastii Jagiellonów ${ }^{65}$.

Dalsze losy podwójnego krzyża stawiają pod znakiem zapytania jego rolę jako godła dynastycznego Jagiellonów. Na pieczęci wielkiej koronnej Jana Olbrachta herb występuje jeszcze w pełni rozwiniętej formie na tarczce pod główną tarczą herbową, co implikuje jego rodową interpretację ${ }^{66}$. Natomiast już na pieczęci większej koronnej Aleksandra zostaje wpisany w wieniec herbów ziemskich i nic nie wskazuje na jego rodową specyfikę ${ }^{67}$. Zmiana w położeniu herbu, a co za tym idzie jego interpretacji, okazała się trwała i od tej pory herb ten zawsze będzie już występował na pieczęciach królów polskich w wieńcu herbów ziemskich. Znaczenie tak wkomponowanego podwójnego krzyża pozostaje nieznane ${ }^{68}$. Można przypuszczać, że przestawał on funkcjonować jako herb rodowy dynastii.

${ }^{63}$ Występowanie równoramiennego herbu na nagrobku Kazimierza Jagiellończyka odnotował już S.K. Kuczyński. Badacz poprzestał jednak na tym wniosku, nie rozwijając wątku; tenże, Polskie herby ziemskie, s. 32.

${ }^{64}$ Już R. Kiersnowski rozróżniał krzyż patriarszy od omówionego ,jagiellońskiego” kształtu krzyża. Równoramienna forma znaku z równo rozłożonymi belkami została nazwana przez badacza (za określeniem występującym w późniejszej redakcji Klejnotów Długosza; por. Klejnoty Dlugoszowe, wyd. M. Friedberg, Kraków 1931, s. 56) jako crux geminata, a więc krzyż bliźniaczy. Jakkolwiek jest to wartościowe rozróżnienie, R. Kiersnowski stwierdza, że taki krzyż miał inną genezę niż patriarszy, przywołując mongolskie i kirgiskie tamgi o zbliżonym kształcie; tenże, Godła jagiellońskie, s. 436, przyp. 69. Koncepcja została najpewniej słusznie odrzucona przez Z. Piecha; tenże, Monety, pieczęcie i herby, s. 262.

${ }^{65}$ Interesująca w tym kontekście jest analiza dekoracji heraldycznej krużganków klasztoru łysogórskiego, które powstały w ramach przebudowy przeprowadzonej za panowania Kazimierza Jagiellończyka. Jednym z częściej występujących symboli na zachowanych do dziś herbach jest podwójny krzyż. Analizując program heraldyczny klasztornych krużganków, Z. Piech przypuszcza, że krzyże takie można uznać zarówno za herb klasztoru, jak i identyfikujący głównego fundatora - króla Kazimierza Jagiellończyka. Za słusznością tej tezy przemawia znamienny kształt owych krzyży występujących na zwornikach przybierają one scharakteryzowaną przeze mnie wyżej, w pełni rozwiniętą postać herbu rodowego Jagiellonów. Mielibyśmy zatem do czynienia z jednoczesną zmianą kształtu godeł na krzyż równoramienny, co wskazuje na dążenie do zachowania tożsamości herbu królewskiego i łysogórskiego. Jest to co najmniej obrazowe odzwierciedlenie specjalnej relacji łączącej dynastię z klasztorem; Z. Piech, Monety, pieczęcie i herby, s. 247; P. Dymmel, Piętnastowieczna dekoracja heraldyczna w krużgankach klasztoru tysogórskiego. Rekonstrukcja, geneza i program, w: Klasztor w społeczeństwie średniowiecznym i nowożytnym, red. M. Derwich, A. Pobóg-Lenartowicz, Opole-Wrocław 1996, s. 265-290 (o herbie zob. s. 281; il. 10, s. 288).

${ }^{66}$ M. Gumowski, Pieczęcie królów polskich, tabl. X, nr 21. Interesującą koncepcję przedstawił Z. Piech, motywując przeniesienie tarczki z krzyżem z dotychczasowej pozycji (ponad główną tarczą herbową) chęcią powielenia schematu znanego z dekoracji heraldycznej nagrobka Kazimierza Jagiellończyka. Choć jest to słuszne spostrzeżenie, ze względu na wciąż niewyjaśnioną problematykę datowania dzieła Stwosza nie jesteśmy w stanie definitywnie tego potwierdzić. Zmiana mogła wynikać z bardziej prozaicznej przyczyny - na głównej tarczy herbowej po raz pierwszy w polskiej sfragistyce królewskiej umieszczono koronę zamkniętą, co wymusiło przeniesienie podwójnego krzyża w inne miejsce; Z. Piech, Monety, pieczęcie $i$ herby, s. 254.

${ }^{67}$ R. Kiersnowski tłumaczy fakt nieumieszczenia tarczki z podwójnym krzyżem centralnie pod główną tarczą herbową względami estetycznymi; tenże, Godła jagiellońskie, s. 467. Jak sądzę, wyjaśnienie badacza nie wyczerpuje problematyki. Na pieczęci większej koronnej Aleksandra po raz pierwszy pojawił się herb jego matki - pas Habsburgów - co pozwala wnioskować, że twórcy programu heraldycznego tej pieczęci niewątpliwie zdawali sobie sprawę ze specyfiki ułożenia herbów rodowych w kompozycji heraldycznej.

${ }^{68}$ W katalogu pieczęci królów polskich, w opisie zabytków sfragistycznych począwszy od Władysława Jagiełły, na Zygmuncie III Wazie kończąc, M. Gumowski określa ten herb jako podwójny krzyż lub podwójny krzyż jagielloński. W odniesieniu do pozycji herbu na pieczęci większej koronnej Aleksandra wysuwa on przypuszczenie, że w tym wypadku można by go wiązać $\mathrm{z}$ Toruniem. Tezę taką można, jak sądzę, odrzucić, niemniej istotne jest zaznaczenie zasadniczej zmiany w funkcjonowaniu herbu, jaka dokonała się za panowania Aleksandra. M. Gumowski stwierdza też, że umieszczenie tego herbu w wieńcu herbów jest konsekwencją niezrozumienia herbu przez rytownika pieczęci; tenże, Pieczęcie królów polskich, s. 22-23. Odnosząc się do tej uwagi, należy stwierdzić, że powyższe niezrozumienie (pozbawienie dotychczasowej rodowej pozycji herbu) nastąpiło już na etapie projektu pieczęci; por. M.A. Janicki, Datowanie plyty nagrobnej Filipa Kallimacha, St. Źródł., 41, 2003, s. 19-43 (o projekcie pieczęci większej koronnej Aleksandra w kontekście przedstawienia pieczęci na płycie Kallimacha zob. s. 28-33). 
Ostatnio na temat dynastycznej kwalifikacji podwójnego krzyża wypowiedział się Z. Piech, stanowczo odmawiając mu miana herbu rodowego, a tym samym dynastycznego ${ }^{69}$. Badacz argumentuje to faktem występowania herbu jedynie w połączeniu z osobą króla polskiego i jego nieobecnością w programach heraldycznych niekrólewskich członków dynastii. Kwestia ta jest jednak bardziej złożona niż przedstawia ją badacz, który kategorycznie rozróżniając podwójny krzyż jagielloński od herbu nowowęgierskiego, nie uwzględnił w swojej analizie zarówno pieczęci węgierskich Władysława, jak i pretendenckiej królewicza Kazimierza. Dalej postaram się wykazać, że istnieją przesłanki sfragistyczne pozwalające przypuszczać, że w XV w. podwójny krzyż mógł funkcjonować zarazem jako herb Węgier, jak i rodowy Jagiellonów.

Mimo że związki jagiellońskiego podwójnego krzyża z herbem nowowęgierskim są znane, występujące między nimi zależności nie doczekały się satysfakcjonującego wyjaśnienia. Jedna $\mathrm{z}$ istniejących koncepcji genezy jagiellońskiego podwójnego krzyża mówi o chęci nawiązania przez Władysława Jagiełłę do tradycji węgiersko-andegaweńskiej poprzednika ${ }^{70}$. Herbem starszym i mającym w omawianym okresie niezmienioną formę jest herb nowowęgierski. Warto tu przypomnieć pokrótce symbolikę i występowanie figury heraldycznej podwójnego krzyża, zwanego też lotaryńskim czy patriarszym, w heraldyce Europy Środkowo-Wschodniej. Najwcześniej, bo już w X w., pojawia się on na półdenarach węgierskiego króla i patrona - św. Stefana. Jest to nawiązanie do przekazania Stefanowi przez cesarza bizantyjskiego Bazylego Bułgarobójcy relikwii części Krzyża Świętego, która była przechowywana w dwuramiennym pektorale. Uznaje się, że podwójny krzyż uzyskał rangę węgierskiego symbolu państwowego za panowania Beli III (1172-1196), który jako pierwszy wprowadził omawiany herb na swą pieczęćc ${ }^{71}$. Następnie poprzez umieszczenie omawianej figury heraldycznej na potrójnej górze utworzono herb zwany nowowęgierskim, do którego w XVII w. dodano jeszcze koronę. Należy podkreślić, że forma herbu nowowęgierskiego była zmienna i w zależności zarówno od okresu, jak i nośnika herbu mógł on być przedstawiany bez wzgórz. Dla interpretacji węgierskich pieczęci Władysława Warneńczyka i Kazimierza istotne jest zwrócenie uwagi na fakt występowania herbu nowowęgierskiego w pełnej formie w sfragistyce Andegawenów (począwszy od pieczęci Ludwika ${ }^{72}$ ) i Luksemburgów ${ }^{73}$. Znamienne, że stopniowy powrót omawianego herbu do wersji bez wzgórz (lub jedynie śladowo zaznaczonych) rozpoczyna właśnie pierwsza pieczęć węgierska Warneńczyka, co analizuję w następnej części artykułu.

Rozpatrując zatem problematykę ikonografii herbu nowowęgierskiego, bierzemy pod uwagę figurę przedstawiającą osadzony na pagórkach podwójny krzyż, którego belki często są rozszerzane przy końcach. Wzniesienia, wraz z dłuższą niższą belką, ówcześnie stanowią zasadniczo najistotniejsze rozróżnienie graficzne między węgierską a jagiellońską wersją herbu ${ }^{74}$. Po wygaśnięciu dynastii Arpadów herb nowowęgierski utrzymał się w heraldyce królestwa Węgier i był wykorzystywany przez przedstawicieli kolejnych dynastii. Można to zaobserwować zwłaszcza za panowania Zygmunta Luksemburga, gdy rosła popularność kultu kolejnego ze świętych królów Węgier, Władysława, z którego osobą również kojarzono podwójny krzyż Arpadów. Z panowaniem Zygmunta na Węgrzech wiąże się jeden szczególny przypadek

69 Z. Piech, Monety, pieczęcie i herby, s. 267-268.

${ }^{70}$ I choć na znanych nam pieczęciach Ludwika jako króla polskiego podwójny krzyż nie występuje (M. Gumowski, Pieczęcie królów polskich, tabl. VIII, nr 11 i 12; por. przyp. 57), to niewątpliwie Jagiełło odwoływał się do węgierskiej tradycji. Prawdopodobnie najwcześniejsze znane występowanie podwójnego krzyża Jagiellonów zachowało się na zworniku w tzw. sali Jadwigi i Jagiełły w Wieży Duńskiej na Wawelu; por. T. Ratajczak, Wieże mieszkalne na zamku wawelskim - badania nad chronologia gotyckiej architektury rezydencji królewskiej, „Rocznik Historii Sztuki”, 39, 2014, s. 189-190. Układ zworników, gdzie podwójny krzyż koresponduje z umieszczonym na sąsiednim zworniku herbem królowej Jadwigi (herb starowęgierski i lilie w słup), bezpośrednio wskazuje na węgierskie konotacje królewskiego herbu. Znamiennym jest ujęcie w tym wypadku krzyża w formie patriarszej, co upodabnia go do formy znanej z herbu nowowęgierskiego - tym samym otrzymujemy substytut pełnej reprezentacji heraldycznej Andegawenów.

${ }^{71}$ G. Székely, Węierskie symbole państwowe $w$ dobie średniowiecza, ich zwiazki z Bizancjum oraz wartości ideowe, Kwart. Hist., 95, 1988, nr 4, s. 32

72 Sigilla regum et reginarum Poloniae, s. 8-9.

73 Por. przyp. 57.

${ }^{74}$ Pozostaje jeszcze kwestia różnych barw herbów, lecz w przypadku wizerunków napieczętnych nie stanowią one czynnika rozróżniającego (o kwestii barw w kontekście namalowanego herbu na zworniku w kaplicy Świętej Trójcy na Zamku Lubelskim zob. Z. Piech, Monety, pieczęcie i herby, s. 246; tam wcześniejsza literatura). 
wykorzystania herbu w wizerunku napieczętnym, który wskazuje na wyjątkowe znaczenie herbu nowowęgierskiego. Jest to jednostronna pieczęć herbowa przedstawiająca herb nowowęgierski, z legendą wskazującą na właściciela pieczęci - Koronę Królestwa Węgier ${ }^{75}$. Jako że powstała w okresie zniewolenia Zygmunta przez stany węgierskie w 1401 r., w praktyce była to pieczęć będąca w dyspozycji panów królestwa.

\section{Węgierskie antecedencje}

Przeprowadzona wyżej analiza funkcjonowania podwójnego krzyża Jagiellonów w XV w. była konieczna dla interpretacji herbu nowowęgierskiego na będącej głównym przedmiotem moich dociekań pieczęci królewicza Kazimierza. Zasadniczą kwestią jest możliwa poliwalencja znaku, a także wskazanie na starania podejmowane w celu odróżnienia herbu Jagiellonów od nowowęgierskiego. W tym kontekście wydaje się, że użycie podwójnego krzyża na pieczęci królewicza Kazimierza ma większy potencjał interpretacyjny niż tylko odwołanie do Zygmunta Luksemburga, co można teraz wykazać, analizując węgierskie pieczęcie Władysława Warneńczyka.

O pierwszej z węgierskich pieczęci tegoż władcy już wspomniałem, przytaczając słuszne spostrzeżenie Z. Piecha o jej związkach z pieczęcią królewicza Kazimierza. Rozważając relacje między tymi pieczęciami, badacz ów stwierdził, że panowanie Warneńczyka było drugim elementem uzasadniającym prawa Jagiellonów do korony Węgier ${ }^{76}$. Stwierdzenie o wywodzeniu praw do korony św. Stefana z elekcyjnych w swej genezie rządów Władysława na Węgrzech ${ }^{77}$ wydaje się niefortunne, choć związki $\mathrm{z}$ węgierskim panowaniem stryja królewicza istnieją i pełnią określoną rolę ${ }^{78}$. Przypuszczam, że znajomość używanej przez Warneńczyka symboliki władzy stanowiła inspirację dla twórcy programu pieczęci Kazimierzowica ${ }^{79}$. Obie reprezentują wykorzystywany przez Jagiellonów typ pieczęci herbowej z czteropolową tarczą, jak również prezentują ten sam zestaw herbów, choć ich kolejność jest odwrócona. Jednakże jeden $z$ elementów kompozycji heraldycznej na pieczęci Warneńczyka w kontekście poczynionych wyżej uwag na temat konotacji herbu nowowęgierskiego i podwójnego krzyża Jagiellonów zasługuje na szczególną uwagę. Nie budzi wątpliwości fakt, że ostatni z herbów na czwórdzielnej tarczy ma być interpretowany przede wszystkim jako herb nowowęgierski ${ }^{80}$. Niezwykle jednak ciekawą jest okoliczność nieumieszczenia krzyża na pagórkach ${ }^{81}$. Przypuszczalnie jest to związane $\mathrm{z}$ faktem zaprojektowania i wykonania tłoku pieczęci w okresie poprzedzającym zmianę wyglądu podwójnego krzyża Jagiellonów, czyli w momencie, gdy rozróżnienie między oboma herbami nie było tak wyraźnie zaznaczone. Niezależnie od słuszności tej hipotezy wprowadzenie na pieczęć królewicza Kazimierza herbu nowowęgierskiego na stosowną pozycję w kompozycji, a więc odpowiadającą podwójnemu krzyżowi na pieczęci Warneńczyka, wskazuje na pewną tożsamość obu herbów ${ }^{82}$.

75 Sigismundus Rex et Imperator, il. 4, s. 14-15.

${ }^{76}$ Z. Piech, Średniowieczne herby, s. 139-140.

77 Na temat elekcji Władysława Warneńczyka zob. K. Olejnik, Władysław III Warneńczyk (1424-1444), Kraków 2007, s. 88-134.

${ }^{78}$ Należy zaznaczyć, że z racji wyboru Władysława na króla węgierskiego nie wynikały żadne prawa dziedziczne. Co więcej, oparcie się na tradycji Warneńczyka uderzałoby zasadniczo w prawa do spadku po Luksemburgach wniesione Jagiellonom przez dziedziczkę Władysława V Pogrobowca, Elżbietę Rakuszankę.

79 Jan Długosz znał omawianą czteropolową kompozycję heraldyczną Władysława Warneńczyka, na co wskazuje zamieszczony w Rocznikach opis florenu węgierskiego Warneńczyka; Ioannis Dlugossi Annales seu Cronicae incliti Regni Poloniae, lib. 11-12: 1431-1444, wyd. K. Baczkowski, L. Korczak, C. Pirożyńska, Warszawa 2001, s. 264. Na ten opis zwrócił uwagę już S.K. Kuczyński w kontekście znaczenia dzieł Długosza jako źródła do heraldyki; tenże, Herby w twórczości historycznej Jana Dtugosza, w: Sztuka i ideologia XV wieku. Materiały sympozjum Komitetu Nauk o Sztuce Polskiej Akademii Nauk, Warszawa 1-4 grudnia 1976 r., red. P. Skubiszewski, Warszawa 1978, s. 211-232, tu s. 220.

${ }^{80} \mathrm{Za}$ Władysława Warneńczyka pierwszy raz umieszczono herb nowowęgierski w jakiejkolwiek kompozycji heraldycznej na tej samej tarczy. Wcześniej na pieczęciach i monetach kładziono go tylko na osobnej tarczy lub umieszczano w polu; P. Wojtowicz, Herb Polski i Litwy na monetach węgierskich, Kraków 1938, s. 28, 31.

${ }^{81}$ M. Gumowski, Pieczęcie królów polskich, tabl. X, nr 22.

${ }^{82}$ Znamienne, że już S.K. Kuczyński przywołał właśnie tę pieczęć Warneńczyka jako drugi przykład (obok większej koronnej) sigillum, w którego programie umieszczono podwójny krzyż; tenże, Polskie herby ziemskie, s. 62, przyp. 118. 
Z podkreśleniem związków między oboma herbami możemy mieć też do czynienia w przypadku drugiej pieczęci węgierskiej Władysława Warneńczyka. Jest to pieczęć herbowa, z tarczą dwudzielną w słup z herbami: starowęgierskim i nowowęgierskim, będąca w użyciu od 23 VII do 19 IX 1444 (o średnicy $57 \mathrm{~mm})^{83}$. Tym razem drugi z herbów przedstawiono w pełnej nowowęgierskiej formie, a więc na pagórkach. W kontekście tej pieczęci warty odnotowania jest fakt, że jest to pierwsza pieczęć, na której zestawiono w opisany sposób na jednej tarczy oba herby węgierskie ${ }^{84}$. Dodatkowo można przypuszczać, że duży rozmiar pieczęci królewicza Kazimierza $(62 \mathrm{~mm})$, podyktowany koniecznością lepszej ekspozycji treści ideowych, był również - obok omówionej wcześniej kwestii podpisu królewicza - celowym nawiązaniem do zwyczajów kancelarii węgierskiej Warneńczyka ${ }^{85}$.

Jeden $\mathrm{z}$ modeli interpretacyjnych programu heraldycznego większej pieczęci węgierskiej Władysława jest zdeterminowany przez luksemburskie, a genetycznie andegaweńskie, stosowanie tarczy dwudzielnej w słup. Przy herbie starowęgierskim, umieszczonym po prawej heraldycznie stronie tarczy, po lewej widniały w przypadku Andegawenów lilie, co stanowi ekspozycję rodowego wątku ${ }^{86}$. Analogiczna tarcza występuje dwukrotnie na pierwszej pieczęci majestatycznej węgierskiej Zygmunta Luksemburskiego $^{87}$, z tym, że lilie andegaweńskie zostają zastąpione przez odpowiednio orła brandenburskiego i lwa czeskiego. Warto zaznaczyć, że Zygmunt w czasie funkcjonowania pieczęci nie był królem Czech, a w legendzie określa się mianem ich dziedzica ${ }^{88}$. Schemat powiela też pierwsza sekretna pieczęć węgierska Zygmunta, przedstawiająca tarczę dwudzielną w słup z herbem starowęgierskim i brandenburskim orłem ${ }^{89}$. Jak można zauważyć, w takiej kompozycji towarzyszący herbowi starowęgierskiemu herb dookreślał osobę właściciela pieczęci i miał wydźwięk rodowy. Zatem jedną z możliwych interpretacji programu heraldycznego na pieczęci większej węgierskiej Władysława Warneńczyka, teoretycznie uzasadnioną w kontekście wskazanej tradycji sfragistycznej, byłoby potraktowanie herbu nowowęgierskiego jako rodowego herbu Warneńczyka. Taka interpretacja dawałaby kolejną przesłankę wskazującą na utożsamienie herbu nowowęgierskiego z podwójnym krzyżem jagiellońskim, co wykraczałoby ponad dotychczasowe ustalenia związane z zależnością między obydwoma herbami.

Powyższa konstatacja ma istotne znaczenie dla pełnej interpretacji programu pieczęci królewicza Kazimierza i pozwala dostrzec złożoność wymowy wizerunku napieczętnego. Stwierdzenie o bliskoznaczności herbu nowowęgierskiego i podwójnego krzyża jagiellońskiego wskazuje na szerszą możliwość odbioru herbu umieszczonego na trzeciej pozycji, będącego formalnie częścią maternum kompozycji heraldycznej. W tym wypadku, w kontekście niewątpliwej korespondencji z pieczęcią stryja, byłoby to odwołanie się do będącego wynikiem elekcji panowania Władysława Warneńczyka, co było zapewne ukłonem względem węgierskich możnych. Wykazane wcześniej funkcjonowanie jagiellońskiego podwójnego krzyża w XV w. zdaje się potwierdzać możliwość szerszej interpretacji, wiążącej herb nowowęgierski z panowaniem Jagiellonów. Jest to jak sądzę istotne, gdyż podkreśla fakt naturalnych praw Kazimierzowica do królestwa Węgier, sprzecznych przede wszystkim wobec roszczeń Habsburgów. To zaś osiągnięto poprzez bezpośrednie heraldyczne odwołanie się do luksemburskiego dziedzictwa, funkcjonującego jako maternum.

${ }^{83}$ Omawiana pieczęć została opublikowana po raz pierwszy w: F. Döry, Ulászló magyar király pecsétjei, „Turul”, 36, 1922, s. 32-33, a do polskiej literatury przedmiotu wprowadził ją Z. Piech (tenże, Monety, pieczęcie $i$ herby, s. 59, il. 4).

${ }^{84}$ Z. Piech, Monety, pieczęcie i herby, s. 59.

${ }^{85}$ Średnica obu omawianych pieczęci odpowiadałaby wielkości ówczesnych pieczęci sekretnych królów Węgier; por. B. Kumorowitz, A magyar királyi egyszerü és titkos pecsét használatának alakulása a középkorban, „Jahrbuch des Graf Klebelsberg Kuno Instituts für ungarische Geschichtsforschung in Wien”, 7, 1937, s. 88.

${ }^{86} \mathrm{Z}$ przykładem omawianej tarczy na kompozycji napieczętnej mamy do czynienia np. na pieczęci majestatowej Ludwika Węgierskiego; M. Gumowski, Pieczęcie królów polskich, tabl. VIII, nr 11. Nie wprost aspekt rodowy drugiej połowy tarczy w kontekście kompozycji heraldycznej za Andegawenów zauważył już P. Wojtowicz, Herb Polski i Litwy, s. 30.

87 Sigismundus Rex et Imperator, s. 180-181, nr 3.3.

${ }^{88}$ Jak sądzę, w ten sposób Zygmunt manifestował swoje prawa do korony w razie bezpotomnej śmierci brata; por. przyp. 18.

${ }^{89}$ Sigismundus Rex et Imperator, s. 180, nr 3.5. 


\section{Antyhabsburska wymowa programu pieczęci}

W kontekście rywalizacji habsbursko-jagiellońskiej należy poruszyć występującą w literaturze przedmiotu kwestię nieobecności pasa Habsburgów na pieczęci królewicza Kazimierza. Zdaniem Z. Piecha herb ten byłby najlepszym sposobem na wyrażenie jagiellońskich praw do tronu Węgier ${ }^{90}$. Znamienny jest też fakt, że I. Sułkowska-Kurasiowa wprowadzając pieczęć do literatury przedmiotu, podała informację, że „wyobraża tarczę herbową czteropolową z Orłem, herbem Habsburgów i Pogonią"91. Być może błędnie dopatrywała się $\mathrm{w}$ herbie starowęgierskim habsburskiego pasa. Zastanawiający jest też fakt podania tylko trzech herbów w kontekście ustalenia przez badaczkę istnienia czteropolowej tarczy herbowej. Nieścisłość w opisie pieczęci pogłębia opis zabytku autorstwa Aleksandry Jaworskiej, która rozpoznała herb starowęgierski i zaznaczyła obecność herbu nowowęgierskiego na pieczęci, jednocześnie wspominając także o obecności pasa Habsburgów. Wraz z rozpoznaniem Orła i Pogoni zwiększa się w ten sposób liczbę herbów tarczy do pięciu, stwierdzając jednocześnie, że tarcza jest czteropolowa ${ }^{92}$. Abstrahując od zademonstrowanych tu niezgodności dotyczących liczby herbów, wskazanie na domniemaną obecność pasa należy uznać za przejaw projekcji oczekiwań badaczy względem omawianej pieczęci królewicza. Przekonanie o niezwykle istotnej roli, jaką pełnił herb rakuski w programach heraldycznych Jagiellonów znajduje dalsze potwierdzenia w historiografii. Także Z. Piech, po poprawnym zidentyfikowaniu herbów na pieczęci, nie kryje zdziwienia brakiem pasa Habsburgów i uznaje pominięcie go za argument przeciw roszczeniowym funkcjom herbu ${ }^{93}$. Ewidentnie tematyka związana $\mathrm{z}$ omawianym herbem wymaga jeszcze wyjaśnienia ${ }^{94}$. Problem leży, jak sądzę, we wciąż nierozpoznanej dostatecznie kwestii stosowania herbu rodowego Habsburgów przez Jagiellonów, na czym zaciążyło przede wszystkim jego stosowanie w XVI w. Pominięcie pasa na pieczęci węgierskiej Kazimierza miało zapewne na celu - jak postaram się wykazać - wykluczenie praw leopoldyńskiej gałęzi dynastii habsburskiej do luksemburskiego dziedzictwa. Wnioski płynące z nieumieszczenia pasa w programie heraldycznym pieczęci są dalej idące i mogą przybliżyć wyjaśnienie wspomnianej problematyki.

Z formalnego punktu widzenia prawa, które nabyli Jagiellonowie poprzez małżeństwo króla Kazimierza Jagiellończyka z Elżbietą Rakuszanką, dotyczyły tylko królestwa Czech (wraz z margrabstwem Moraw i Śląskiem) i Węgier ${ }^{95}$. Wiąże się to $\mathrm{z}$ faktem zezwolenia na ślub przez ówczesną głowę rodu, cesarza Fryderyka III, pod warunkiem zrzeczenia się przez Elżbietę praw nie tyle do Austrii, ile do dziedzicznych krajów Habsburgów („ducatus et dominiorum Domus Austriae”) ${ }^{96}$. Dla dalszych rozważań zasadnicze będzie przypomnienie, że Rakuszanka należała do starszej, albertyńskiej linii dynastii Habsburgów, która poprzez małżeństwo jej ojca Albrechta II z jedyną dziedziczką cesarza Zygmunta Luksemburskiego zyskała prawa do wspomnianych królestw. Istotny w tym kontekście jest fakt powszechnego uznawania możliwości przekazywania praw dziedzicznych przez kobiety swoim męskim potomkom, podczas gdy one same były z dziedziczenia wykluczone ${ }^{97}$. Na tej podstawie po śmierci cesarza Zygmunta poprzez małżeństwo Albrechta II z dziedziczką Luksemburgów Elżbietą trony Czech i Węgier objęli przedstawiciele albertyńskiej linii Habsburgów. Znajduje to wyraz w przyswojeniu sobie przez samych Habsburgów albertyńskich tradycji luksemburskiej, co jest widoczne w zabytkach sfragistycznych, począwszy od Albrechta $\mathrm{II}^{98}$. Analogicznie po śmierci Władysława V Pogrobowca prawa do obu

90 Z. Piech, Monety, pieczęcie i herby, s. 85.

${ }^{91}$ I. Sułkowska-Kurasiowa, Polska kancelaria królewska, s. 74.

92 A. Jaworska, Orzet Biaty, s. 92.

93 Z. Piech, Austriacki herb Habsburgów, s. 588.

${ }_{94} \mathrm{~W}$ artykule ograniczam się tylko do analizy pasa w kontekście pieczęci królewicza Kazimierza. Problematyka związana ze stosowaniem herbu Habsburgów przez Jagiellonów wymaga osobnego opracowania.

95 Por. przyp. 30.

96 Codex diplomaticus Regni Poloniae et Magni Ducatus Lituaniae, t. 1, Austria, nr V, s. 156; por. R. Heck, Zjazd glogowski w 1462 r., Wrocław 1962, s. 16 (zwł. przyp. 43-46).

97 K. Baczkowski, Walka o Węgry, s. 17.

98 Z. Piech przywołuje częste występowanie pasa habsburskiego na pieczęciach Albrechta II i Władysława V, stwierdzając, że odgrywa ważną rolę; tenże, Austriacki herb Habsburgów, s. 570. Jest to oczywiście słusznie stwierdzenie, które na potrzeby 
tronów przeszły na jego siostry - Annę i Elżbietę. Ważną w tym kontekście kwestią jest to, że choć Elżbieta była młodszą z sióstr, Anna, która wyszła za landgrafa Turyngii Wilhelma III, doczekała się jedynie córek ${ }^{99}$. Ta okoliczność sprawiła, że jedynymi męskimi dziedzicami Luksemburgów w linii prostej stali się synowie polskiej pary królewskiej.

Wydaje się zatem, że brak pasa habsburskiego na pieczęci ma dwie, powiązane ze sobą przyczyny, które też wyjaśniają występujący na niej dobór herbów. Omawiany herb był ówcześnie postrzegany przede wszystkim jako rodowy Habsburgów ${ }^{100}$, silnie eksponowany przede wszystkim przez młodszą, leopoldyńską linię dynastii w osobie cesarza Fryderyka III. Cesarz zawierając w 1463 r. układy w Wiener-Neustadt i Sopronie, otworzył nowy rozdział w rywalizacji habsbursko-jagiellońskej. Jak już wspomniano, traktaty gwarantowały Habsburgom następstwo tronu po Macieju Korwinie, który uznał dziedziczne prawa Fryderyka do korony św. Stefana, wynikające z bycia najbliższym krewnym po mieczu Władysława V Pogrobowca ${ }^{101}$. Ponadto cesarz adoptował Macieja Korwina, zyskując też prawo do używania tytułu króla Węgier. Warto zaznaczyć, że powołanie się na ten tytuł w traktacie sojuszniczym z Kazimierzem Jagiellończykiem stało się oficjalnym powodem odmowy jego ratyfikacji przez polskiego króla ${ }^{102}$. Widać, że pas Habsburgów nie spełniałby swej funkcji w kompozycji heraldycznej na pieczęci, jeśli nie zacieśniałby kręgu prawowitych władców Węgier do męskiego potomstwa Elżbiety. Należało zatem podkreślić to, co dawało Kazimierzowicom prawa przewyższające te posiadane przez Leopoldynów, które manifestował Fryderyk III. Rozwiązaniem było wykorzystanie, jak już zaznaczyłem, ówcześnie przysługującej jedynie Jagiellonom symboliki Luksemburgów. Stąd też (wbrew przypuszczeniom Z. Piecha) pas habsburski w kompozycji heraldycznej pieczęci królewicza Kazimierza zasadniczo byłby kontradykcją treści ideowych zawartych w pieczęci.

\section{Podsumowanie}

Wziąwszy pod uwagę powyższe spostrzeżenia, należałoby interpretować symbolikę pieczęci królewicza Kazimierza jako znak predestynacji na tron węgierski. Wyrazem tego, jak starałem się wykazać, jest genealogiczny w swej istocie jej program, wskazujący na Kazimierza jako najgodniejszego, najbardziej uprawnionego kandydata na tron. Motyw dynastyczny, będący zarazem zakwestionowaniem praw Habsburgów z linii Leopoldynów, wskazywał na właściwego króla Węgier zgodnie z zasadami dziedziczenia tronu. Połączono go z odwołaniem się do tradycji elekcyjnej, mającej uzyskać poparcie węgierskich możnych. Osiągnięto to poprzez ikonograficzną i ideową korespondencję z pieczęciami rządzącego w wyniku elekcji Władysława Warneńczyka, pod pretekstem maternum, co tworzyło wizerunek kandydata do tronu, którego władza miałaby silne umocowanie w tradycji państwowo-dynastycznej.

prowadzonych rozważań należałoby dookreślić. Widoczne jest umiejscowienie herbu najczęściej jako pełniącego funkcje osobistego - na tarczy jeźdźca przy pieczęci konnej Albrechta, u stóp postaci tronującej na pieczęci majestatycznej, czy też samodzielnie na pieczęci sygnetowej; O. Posse, Die Siegel der Deutschen Kaiser und Könige, t. 2, Drezno 1910, tab. 19, 20. Warto zwrócić uwagę na pieczęć sekretną Władysława Pogrobowca, która przedstawia czteropolową tarczę z herbami: I - starowęgierskim, II - lwem czeskim, III - pasem Habsburgów, IV - orłem morawskim; B. Kumorowitz, A magyar királyi, s. 109-110. Widać, że pas - herb o niewątpliwie rodowej dystynkcji - znajduje się na analogicznym miejscu co herb nowowęgierski na pieczęci królewicza Kazimierza.

99 Błędne stwierdzenie zawiera biogram królowej w PSB autorstwa Józefa Garbacika, jakoby synem siostry Elżbiety był wielki mistrz zakonu krzyżackiego Fryderyk Wettyn; J. Garbacik, Elżbieta Rakuszanka, w: PSB, t. 6, Kraków 1948, s. 253.

100 Z. Piech, Austriacki herb Habsburgów, s. 570.

101 K. Baczkowski, Wokót elekcji Władysława na tron węgierski w 1490, w: Ojczyzna bliższa i dalsza. Studia historyczne ofiarowane Feliksowi Kirykowi w sześćdziesiąta rocznice urodzin, red. J. Chrobaczyński, A. Jureczek, M. Śliwa, s. 375-386, tu s. 375.

102 Tenże, O rzekomym kongresie $w$ Villach $w$ lipcu 1470 r., St. Hist., 23, 1980, nr 1(88), s. 115-119. Badacz ten twierdzi, że użycie przez Fryderyka III tytułu króla Węgier było tylko pretekstem nieratyfikowania traktatu, faktyczną przyczyną był zaś brak konkretnych zobowiązań względem Jagiellonów wobec narastającego konfliktu z Maciejem Korwinem (tamże, s. 115), a także obawa przed naruszeniem praw dziedzicznych Jagiellonów do koron czeskiej i węgierskiej; tenże, Między czeskim utrakwizmem, s. 25. 
Podkreślało to też atrakcyjność reprezentowanego przez Jagiellonów modelu politycznego - monarchii samoograniczającej się i współpracującej ze stanami, w opozycji do rządów Macieja Korwina ${ }^{103}$. Działania dworu krakowskiego wpisywałyby się też w kształtującą się praktykę ograniczenia elekcji do członków dynastii - w kontekście węgierskim do bezpośrednich spadkobierców tradycji sięgającej czasów andegaweńskich. Podkreśleniem tego jest użycie w tytulaturze terminu naturalis heres, które miało wyrażać realne znaczenie tych praw, usuwając zarazem podejrzenie o uzurpację.

Taka interpretacja znajduje bardzo bliską analogię, jaką jest objęcie tronu w Czechach przez Władysława II Jagiellończyka, pierworodnego syna polskiej pary królewskiej. Model przejęcia władzy byłby zasadniczo taki sam, z tą zasadniczą różnicą, że elekcja nastąpiła po naturalnym zgonie uznanego władcy, bez potrzeby strącania aktualnie rządzącego ${ }^{104}$. W kontekście objęcia tronu przez Władysława Krzysztof Baczkowski zauważa, że związki pokrewieństwa z poprzednią dynastią stanowiły tu ważny argument, ale służyły przede wszystkim jako zabezpieczenie wyniku elekcji (uznawanej zresztą w czeskiej historiografii za pierwszą wolną) przed zagrożeniem zewnętrznym ${ }^{105}$. Jeśli natomiast spojrzy się na całość polityki zewnętrznej głównego sprawcy tych wydarzeń - króla Kazimierza Jagiellończyka dostrzec można wspólny mianownik. Byłoby nim wygrywanie własnych, dynastycznych w swej istocie interesów na arenie międzynarodowej poprzez wykorzystywanie konfliktów między stanami a rządzącymi. Z powodu - jak okazało się dopiero w trakcie wyprawy królewicza - nikłego poparcia wśród stanów węgierskich, które uznały elekcję Korwina za pełnoprawną, nie udało się powtórzyć sukcesu z Prus i częściowego sukcesu z Czech. Jagiellonowie objęli tron Węgier dopiero po śmierci Korwina w 1490 r., kiedy to z bratobójczej wojny między Janem Olbrachtem a Władysławem II Jagiellończykiem zwycięsko wyszedł ten drugi.

\section{The seal of Prince Casimir Jagiello from the period of his claims to the Hungarian Crown and its political programme}

Summary: The purpose of the study is to show the significance of the "Hungarian" seal of Prince Casimir Jagiello (the second son of King Casimir IV of Poland and future saint of Catholic Church) in the context of the rivalry between the Jagiellons, Habsburgs and Corvinus in the third quarter of the fifteenth century. After the introduction, the author presents a description of the seal, which has not been published until now, although it is known to the literature on the subject. Based on the preserved diplomatic source material, he attempts to reconstruct its inscriptions. In the next chapter, the author outlines the historical context of the creation and functioning of the seal, with special attention to issues related to the inheritance of the Czech and Hungarian thrones. The author then attempts a new interpretation of the political and ideological programme of the seal as the manifestation of hereditary rights of Prince Casimir to the Hungarian throne. At the same time, its programme is compared to the first Hungarian seal of King Władysław III of Varna, with emphasis on similarities and differences between them. Next, the author suggest a genealogical interpretation of the seal. The following chapter is devoted to the analysis of the relationship between the two coexisting coats of arms: the Double Cross of the Jagiellons and the Double Cross of Hungary; the author emphasises the possibility of a certain similarity between the coats of arms affecting the interpretation of the seal. In the next chapter, the researcher examines the Hungarian seals of Ladislaus of Varna, and suggests that in his ideological and political programme Prince Casimir referred to the reign of his uncle. In the light of the sources quoted earlier, the author suggests that this was purposeful in order to obtain the support of the Hungarian nobles. In the last chapter, the historian points to the lack of the Habsburg coat of arms on the seal, which has not been explained in the literature on the subject. In the summary, the conclusions of all discussed subjects are presented. It is emphasised how the political programme of the seal fulfilled the needs of current policy of the House of Jagiellons.

${ }_{103}$ Tenże, Idea jagiellońska, s. 68.

${ }^{104}$ W związku z czym Władysław nie był zmuszony używać pieczęci pretendenckiej, analogicznej do tej, której używał królewicz Kazimierz. Pieczęć Władysława jako króla czeskiego sporządzono już po przybyciu do Pragi, co odnotował w prowadzonych rachunkach wyprawy ówczesny podskarbi nadworny Tomasz Trąpczyński; Rachunki królewskie z lat 1471-1472 i 1476-1478, wyd. S. Gawęda, Z. Perzanowski, A. Strzelecka, Wrocław 1960, s. 86.

105 K. Baczkowski, Między czeskim utrakwizmem, s. 18, 46. 
Nota o autorze: Szymon Titkow, mgr, absolwent Instytutu Historycznego Uniwersytetu Warszawskiego, doktorant Szkoły Doktorskiej Nauk Humanistycznych Uniwersytetu Warszawskiego.

Author: Szymon Titkow, MA, graduate of the Institute of History of the University of Warsaw, student of the Doctoral School of Humanities, University of Warsaw.

Szkoła Doktorska Nauk Humanistycznych Uniwersytetu Warszawskiego

ul. Krakowskie Przedmieście 1

00-047 Warszawa

e-mail: s.m.titkow@student.uw.edu.pl

\section{Bibliografia}

Baczkowski K., Między czeskim utrakwizmem a rzymska ortodoksja czyli walka Jagiellonów z Maciejem Korwinem o koronę czeska w latach 1471-1479, wyd. 2 popr., poszerz. i uzup., Oświęcim 2014

Baczkowski K., Walka o Węgry w latach 1490-1492. Z dziejów rywalizacji habsbursko-jagiellońskiej w basenie środkowego Dunaju, „Zeszyty Naukowe Uniwersytetu Jagiellońskiego. Prace Historyczne”, 116, 1995, s. 7-168

Biskup M., Die dynastische Politik der Jagiellonen um das Jahr 1475 und ihre Ergebnisse, „Österreichische Osthefte", 18, 1976, s. 203-217

Biskup M., Die Rivalität zwischen Jagiellonen und Habsburgern um die böhmische und die ungarische Krone im 15. und Anfang des 16. Jahrhunderts, „Österreichische Osthefte”, 32, 1990, nr 2, s. 269-285

Heck R., Elekcja kutnohorska 1471 r., Sobótka, 27, 1972, nr 2, s. 194-235

Hlebionek M., Pieczęcie polskich królewiczów, „Сфрагістичний щорічник”, 4, 2013, s. 158-184

Kiersnowski R., Godta jagiellońskie, w: Historia, pieniadz, herb. Opera selecta, red. S.K. Kuczyński, S. Suchodolski, Warszawa 2008, s. 447-471

Kuczyński S.K., Polskie herby ziemskie: geneza, treści, funkcje, Warszawa 1993

Piech Z., Austriacki herb Habsburgów w heraldyce Jagiellonów, w: Nihil superfluum esse. Prace z dziejów średniowiecza ofiarowane Profesor Jadwidze Krzyżaniakowej, red. J. Strzelczyk, J. Dobosz, Poznań 2000, s. 565-594

Piech Z., Monety, pieczęcie $i$ herby w systemie symboli władzy Jagiellonów, Warszawa 2003

Piech Z., Pieczęcie herbowe w systemach sfragistycznych dawnej Rzeczypospolitej, w: Dawne pieczęcie. Typologia, metody badań, interpretacje, red. Z. Piech, Warszawa 2015, s. 207-253

Piech Z., Średniowieczne herby w katedrze wawelskiej. Treści i funkcje, w: Katedra krakowska w średniowieczu. Materiały sesji Oddziału Krakowskiego Stowarzyszenia Historyków Sztuki. Kraków kwiecień 1994, red. J. Daranowska-Łukaszewska, K. Kuczman, Kraków 1996

Potkowski E., Podpisy królów polskich, „Miscellanea Historico-Archivistica”, 2, 1987, s. 5-38

Sułkowska-Kurasiowa I., Dokumenty królewskie i ich funkcja w państwie polskim za Andegawenów i pierwszych Jagiellonów 1370-1444, Warszawa 1977

Sułkowska-Kurasiowa I., Polska kancelaria królewska w latach 1447-1506, Warszawa 1967

Székely G., Węgierskie symbole państwowe w dobie średniowiecza, ich związki z Bizancjum oraz wartości ideowe, Kwart. Hist., 95, 1988, nr 4, s. 21-33

Szybkowski S., Nieznana pieczęć królewicza Kazimierza z 1482 roku, Rocz. Hist., 81, 2015, s. 189-197 